\title{
Article
}

http://dx.doi.org/10.11646/phytotaxa.239.2.1

\section{Clarification of Massonia echinata and some other frequently misunderstood Massonia species (Asparagaceae, Scilloideae), with the description of M. pseudoechinata and M. roggeveldensis}

\author{
MARIO MARTÍNEZ-AZORÍN ${ }^{1,2 *}$, MICHAEL PINTER ${ }^{1}$, MANUEL B. CRESPO ${ }^{2}$, JULIAN SLADE ${ }^{3}$, GERFRIED \\ DEUTSCH$^{1} \&$ WOLFGANG WETSCHNIG ${ }^{1 *}$ \\ ${ }^{1}$ Institute of Plant Sciences, NAWI Graz, Karl-Franzens-University Graz, Holteigasse 6, A-8010, Graz, Austria. e-mail: wolfgang. \\ wetschnig@uni-graz.at; mmartinez@ua.es \\ ${ }^{2} d C A R N \&$ CIBIO (Instituto Universitario de la Biodiversidad), Universidad de Alicante, P. O. Box 99, E-03080 Alicante, Spain. \\ ${ }^{3}$ P.O. Box 1182, Mount Barker SA 5251, Australia. \\ *author for correspondence
}

\begin{abstract}
As part of a taxonomic revision of the genus Massonia, we here clarify concepts of Massonia echinata, M. latebrosa and M. tenella - all frequently misunderstood or reduced to synonymy. We discuss their history, biology, habitat preferences and distribution. Our study also shows that the current concept of $M$. echinata, including $M$. angustifolia and M. lanceolata as synonyms, includes two unpublished species which we here describe as M. pseudoechinata and M. roggeveldensis. A new combination in Massonia is proposed for Haemanthus sessiliflorus.
\end{abstract}

Key words: Southern Africa, Hyacinthaceae, Massonieae, Taxonomy, Massonia angustifolia, M. lanceolata, M. latebrosa, M. sessiliflora, M. tenella

\section{Introduction}

Asparagaceae subfamily Scilloideae tribe Hyacintheae is alternatively regarded as Hyacinthaceae subfam. Hyacinthoideae, a treatment that we here favour. Further information on the subfamily Hyacinthoideae and generic circumscriptions can be found in Martínez-Azorín et al. (2013, 2014a, 2014b), Pinter et al. (2013) and Wetschnig et al. (2014).

The genus Massonia Houttuyn (1780: 424) belongs to subfamily Hyacinthoideae tribe Massonieae (Speta 1998a, 1998b, Wetschnig et al. 2002, Pfosser et al. 2003, Manning et al. 2004) and is confined to South Africa and southwestern Namibia. This genus was described to include a single species, Massonia depressa Houttuyn (1780: 424). With ongoing exploration of the southern African flora, the number of species in Massonia quickly increased, reaching 33 species accepted by Baker (1897). However, recent studies in Massonia reduced the number of accepted species to 6 (van der Merwe 2002, Manning \& Goldblatt 2003, Summerfield 2004), 8 (Jessop 1976), 12 (Müller-Doblies \& Müller-Doblies 1997) or 14 (Species-2000 2015).

Our studies in Massonia reveal that the taxonomy of the genus, as presented in recent revisions, is not satisfactory and several species concepts have been overlooked and misunderstood (Wetschnig et al. 2012, 2014, Martínez-Azorín et al. 2013, 2014a, 2014b, 2015, Pinter et al. 2013, 2015).

Within the framework of a taxonomic revision of Massonia, the study of herbarium vouchers, including the type specimens, as well as living plants from wild populations in South Africa and cultivated material, revealed that the concepts of Massonia echinata Linnaeus (1782: 193), M. angustifolia Linnaeus (1782: 193), M. latebrosa Masson ex Baker (1886: 336) and M. tenella Sol. ex Baker (1870: 389) as accepted in recent revisions (Jessop 1976, MüllerDoblies \& Müller-Doblies 1997, van der Merwe 2002, Manning \& Goldblatt 2003, 2013, Summerfield 2004) have been misunderstood and some of these names were reduced to synonymy, yet they indeed represent distinct species based on clear morphological characters and biogeography.

Our studies show that the concept of Massonia echinata as presented by Müller-Doblies \& Müller-Doblies (1997) 
corresponds to an undescribed species related to M. mimetica Martínez-Azorín et al. (2013: 191) and M. bakeriana Pinter et al. (2015: 52), which is here described as Massonia pseudoechinata. Plants from the Roggeveld, which were illustrated by Aiton (1789) and Ker Gawler (1804) under the name M. angustifolia, strongly differ from the type material of both M. angustifolia and M. lanceolata - these belong to a new species, here named Massonia roggeveldensis. A complete morphological description for all these species is presented below, including data on habitat, ecology, and distribution.

Finally, a new combination in Massonia is proposed for Haemanthus sessiliflorus, since the combination made by Müller-Doblies \& Müller-Doblies (1997) is deemed invalid as the basionym was not included in full (Art. 41.5 Melbourne Code, McNeill et al. 2012).

\section{Materials and Methods}

Detailed morphological studies of Massonia were undertaken on natural populations, cultivated specimens and herbarium vouchers, as elaborated upon in Martínez-Azorín et al. (2007, 2009). Herbarium specimens from the herbaria ABH, B, BLFU, BM, BOL, E, G, GZU, GRA, HAL, K, L, LINN, M, MO, NBG, NU, NY, P, PRE, S, TCD, UPS, WU, Z, ZSS and ZT (acronyms according to Thiers 2015) were studied. Authors of the cited taxa follow IPNI (2015). Orthography of geographical names and grid-number system follows Leistner \& Morris (1976). SEM-micrographs of the leaf surface: an $8 \times 5 \mathrm{~mm}$ section of one fresh leaf was fixed in $70 \%$ ethanol. After substitution of ethanol by acetone, critical point drying was performed using a Baltec CPD030. The leaf was then mounted on aluminium stubs and coated with gold in an Agar sputter coater. Electron micrographs were obtained with a Philips XL 30 ESEM scanning electron microscope (SEM) operating at $20 \mathrm{kV}$. The WW numbers correspond to the accession numbers of the living plant collection cultivated at the Botanical Garden of the Institute of Plant Sciences of the University of Graz.

\section{Clarification of four Massonia species}

\section{The case of Massonia echinata}

Massonia echinata was described by Linnaeus (1782, April) as "echinata. MASSONIA foliis ovatis muricatis pilosis. Habitat in Cap. bonae Spei. Thunberg." Soon after, Thunberg (1782 July, 1783) added the following information: "Crescit juxta margines montis, dictae Bocklands Berg, in interioribus Capitis bonae Spei regionibus" and "Folia radicalia, duo, ovata, obtusa cum acumine, integra, plana, depressa, tota supra tuberculis muricata, pilosa pilis sparsis albis, pollicaria".

Thunberg and Masson, on their second joint trip into the interior of South Africa (September-December 1774), climbed the Bokkeveld Mountains on the $2^{\text {nd. }}$ of November 1774 (Forbes 1986). Then they turned south, and finally, at the night of $4^{\text {th }}$ of November 1774 (see Masson 1776: 311), they arrived to the farm of Klaas Losper (Forbes 1986). This farm was situated where Nieuwoudtville was later established. On $6^{\text {th }}$ of November, they left this farm and continued their journey heading for the Hantamsberg region. It appears therefore that the original collection of Massonia echinata by Thunberg was most probably made on the $5^{\text {th }}$ of November 1774 . This collection represents, as far as we know, the first recorded finding of any Massonia species. This is remarkable since, up to now, Masson, who later on the same trip found Massonia latifolia [M. depressa agg.] in the Roggeveld, has always been regarded as the discoverer of the first Massonia, his name being used by Houttuyn (1780: 424) to describe the genus.

Apparently, only Thunberg found M. echinata on that trip, as Masson never sent bulbs of this species to Kew in 1775 (Aiton 1789). The hypothesis that Masson did not know the real identity of M. echinata is supported by the fact that Masson sent bulbs identified as M. echinata from his second visit to South Africa to England, which in fact later turned out to belong to a different family: "The bulb which I sent last year under the name of Massonia echinata has flowered and proves to be a new sp. of Amaryllis“" [Masson in a letter on $2^{\text {nd }}$ of June 1790 to J. Banks - see Bradlow (1994: 66)]. Another proof of Masson's uncertainty about the identity of M. echinata is that Masson's painting nr. 111 kept at BM and named "Massonia echinata?" is regarded to belong to M. pygmaea subsp. pygmaea sensu MüllerDoblies \& Müller-Doblies (1997). According to Aiton (1811), Masson sent bulbs of Massonia echinata to Kew in 1790. Unfortunately we have no more information on the locality and the collection date.

Massonia echinata was later accepted by most researchers working on Massonia, such as Panzer (1784), Thunberg (1794, 1818), Aiton (1811), Kunth (1843), Baker (1870, 1897), Jessop (1976), Müller-Doblies \& Müller-Doblies 
(1997), van der Merwe (2002), Manning \& Goldblatt (2003, 2012, 2013) and Summerfield (2004). However, it seems that this species has been widely misunderstood and the name has been misapplied from the beginning of the nineteenth century.

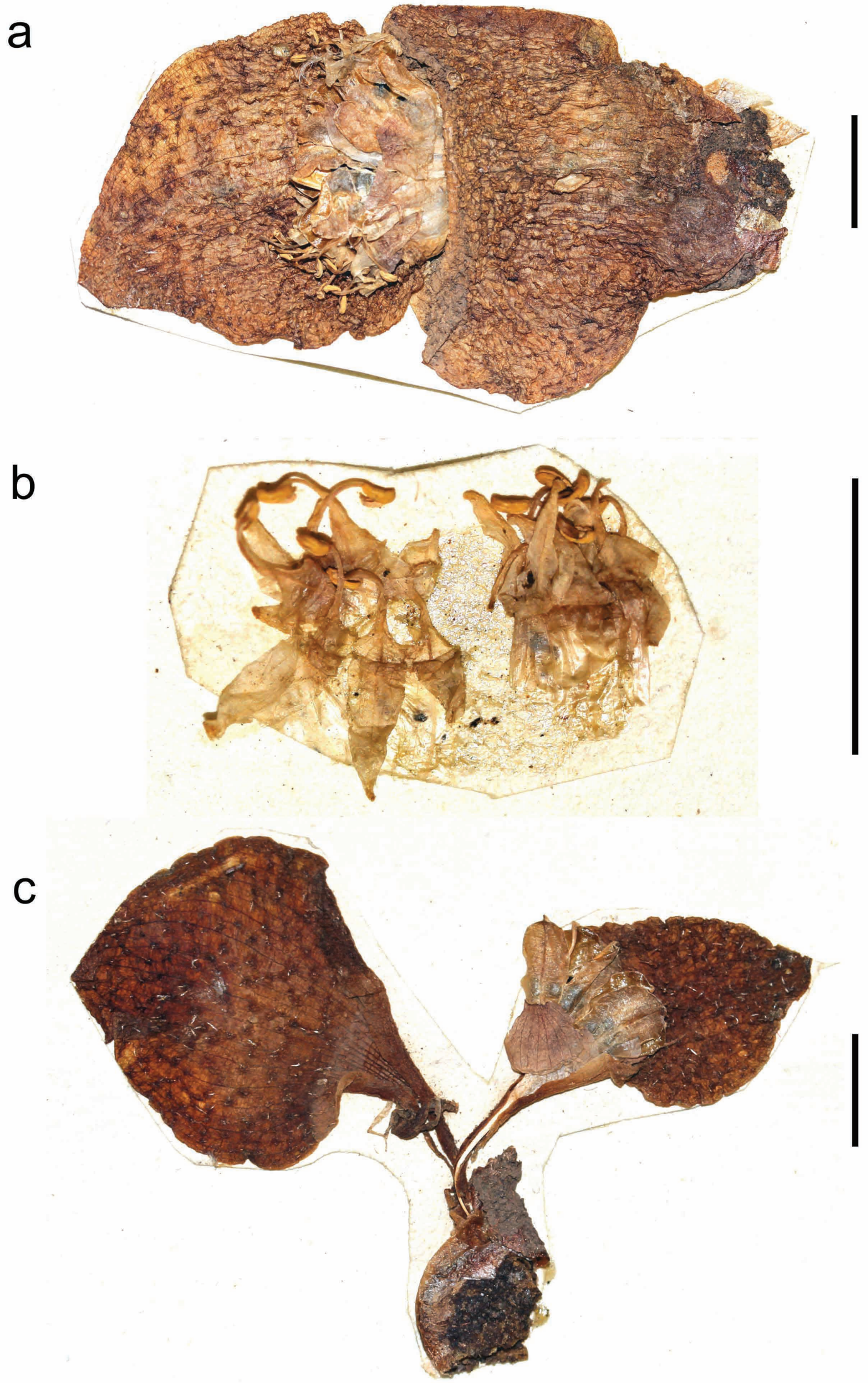

FIGURE 1. Materials included in the lectotype of Massonia echinata L.f. (UPS-THUNB7988). a. Plant in fruit; b. Perigone and stamens of flowers, most probably taken from the plants in fruit; c. Plant in fruit. Scale bars $1 \mathrm{~cm}$. 
Aiton (1811) regarded M. echinata as having "laciniis corolla filiformibus", but the type material of the species (UPS-THUNB 7988, Fig. 1) shows a widely lanceolate free portion of the tepals. It is probable that Aiton's description was influenced by the existence of a Masson's drawing at BM (no. 111) where a plant in flower was depicted in 1794 from material collected at "Summis montarum (Camiesberg) in fissures rupis planis vastis (Granit) in 1793" [sic] and named "Massonia echinata?". It shows long spreading filaments, dark anthers, long, reflexed, thin free portion of perigone segments, and leaves bearing numerous, erect, white trichomes. However, this combination of characters strongly differs from the type material of M. echinata, yet agrees with Massonia pygmaea subsp. pygmaea sensu Müller-Doblies \& Müller-Doblies (1997).

Aiton's concept of M. echinata was apparently followed by Baker $(1870,1897)$ who added the drawing by Masson cited above and the collection Zeyher 1717 to the type collection by Thunberg, and described the leaves as having "conspicuous whitish bristles".

Jessop (1976) and van der Merwe (2002) included 22 and 17 heterotypic synonyms respectively in Massonia echinata, resulting in a broad species concept, including plants extremely variable regarding leaf, flower and fruit characters. Furthermore, Jessop (1976) indicated the collection UPS-THUNB7988 as the 'holotype' of the M. echinata. However, two further sheets exist in Stockholm in the Herbarium of Thunberg's students Montin and Alstroemer (S10-14231, S10-14232) identified as Massonia echinata and include plants collected by Thunberg and matching the protologue. As no evidence exists that any of those sheets was the only material studied by Linnaeus fil., we consider them all as syntypes and therefore Jessop's selection is to be regarded as lectotype (Art. 9.9, McNeill et al. 2012).

Müller-Doblies \& Müller-Doblies (1997) circumscribed M. echinata in a much narrower sense, being only known to them from Vanrhyns Pass and the Karoo National Park. These specimens were characterised by the "sigmoid curve at the base of the tepal segments combined with a more or less open throat of the filaments tube and with pustulate leaves, bearing one to few short stiff hairs on each pustule". Moreover, Müller-Doblies \& Müller-Doblies (1997: 71) illustrated a dissected flower from the type collection of $M$. echinata (Fig. 1b) together with a flower from Vanrhynspas (Müller-Doblies 77060c), from near the type locality, and another one from the Karoo National Park (Müller-Doblies $84057 \mathrm{c}$ ), all presented to the same scale. The dimensions of the stamen and free portion of tepals in the type collection strongly differ from those in the two cited Müller-Doblies collections, where they show much longer filaments and smaller perigone segments.

The type material of M. echinata includes flowers with short and wide perigone-filaments tubes, ca. $5 \mathrm{~mm}$ long, not completely enclosing the ovary and filaments connate at the base for ca. $1 \mathrm{~mm}$ long, greatly differing from the dimensions presented by Müller-Doblies \& Müller-Doblies (1997) for M. echinata, with a much longer and narrower perigone tube (9-13 $\mathrm{mm}$ long), and a deeply included ovary. Furthermore, the leaves in the holotype are relatively small, 2-4 cm long and bear distinct pustules with a thickened, deflexed trichome on top. The plants illustrated by MüllerDoblies \& Müller-Doblies (1997) from the Karoo National Park represent a recently described species M. dentata Martínez-Azorín et al. (2014a: 203), and the one from Vanrhyns Pass is described below as M. pseudoechinata.

Manning \& van der Merwe (2002a), Manning \& Goldblatt (2003, 2013) and Summerfield (2004) accepted M. echinata sensu Müller-Doblies \& Müller-Doblies (1997), based on the morphology presented for that species, and included M. angustifolia, M. bolusiae, M. hirsuta and M. setulosa as synonyms, combining very different morphologies in that species concept.

The study of living plants (Figs. 2, 3a, 4a, 5a) and herbarium material from the vicinity of Oorlogskloof near Nieuwoudtville, corresponding generally to the type locality of M. echinata (Müller-Doblies \& Müller-Doblies 1997), perfectly fit the holotype of that species, and reveals that the current concept of $M$. echinata sensu Müller-Doblies \& Müller-Doblies (1997) and Manning \& Goldblatt $(2003,2012)$ greatly deviates morphologically from the holotype and the original concept of that species. A complete description of M. echinata is presented below.

Massonia echinata Linnaeus fil. (1782: 193)

Type (designated by Jessop: 1976: 414 as 'holotype'):-SOUTH AFRICA. [Western Cape, 3118 (Vanrhynsdorp)]: “Crescit juxta margines montis, dictae Bocklands Berg, in interioribus Capitis bonae Spei regionibus", probably on 5 November 1774, Thunberg s.n. (lectotype UPS-THUNB7988!, Fig. 1; isolectotypes S10-14231!, S10-14232!).

Deciduous geophyte. Bulb ovoid to subglobose, $0.8-2 \times 0.8-1.8 \mathrm{~cm}$, with white fleshy bulb scales, covered by papery, purplish, inner tunics and brown, outer tunics. Leaves 2, synanthous, opposite, appressed to the ground, ovoid to suborbicular with obtuse apex, $\operatorname{limb} 2-7.5 \times 1.5-6 \mathrm{~cm}$, with a short apicule up to $1 \mathrm{~mm}$ long, with narrow, membranous, minutely papillose margins; adaxial side green, with (10-)15-30 symmetrical, cone-like emergences per $\mathrm{cm}^{2}$, which are $0.8-3.5 \mathrm{~mm}$ in diameter, with a narrowly conical, declined, smooth, trichome on top ca. $0.4-1 \mathrm{~mm}$ long; abaxial 


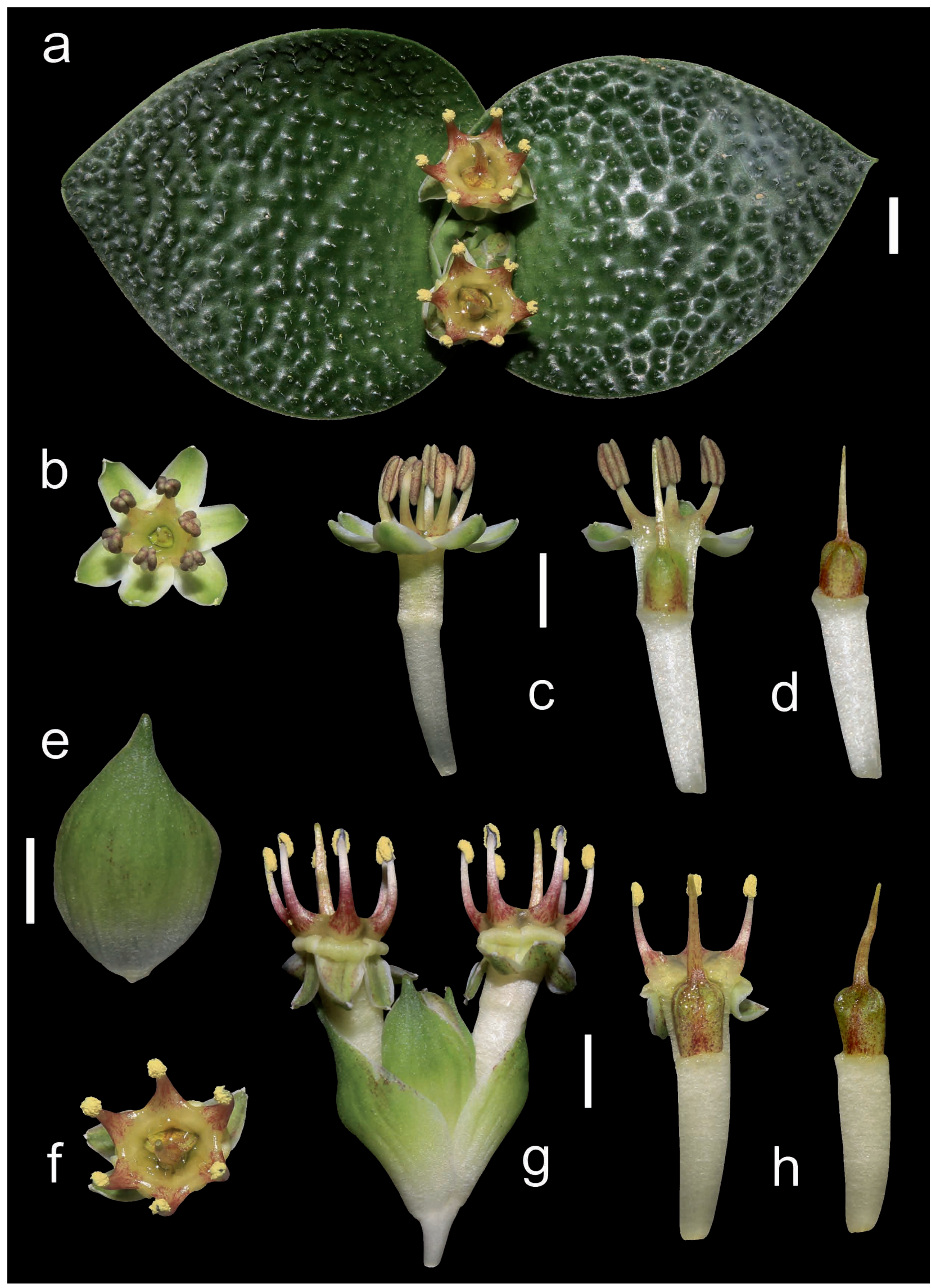

FIGURE 2. Massonia echinata L.f. in cultivation grown from seeds from Oorlogskloof in the Northern Cape province of South Africa (corresponding to WW04916). a. Plant in apical view; b. Flower with closed anthers, apical view; c. Flower and dissected flower with closed anthers, lateral views; d. Gynoecium, lateral view; e. Bract, lateral view, abaxial side; f. Flower with open anthers, apical view; g. Inflorescence, lateral view; h. Dissected flower with open anthers and gynoecium, lateral views. Scale bars $5 \mathrm{~mm}$. 
side smooth, green; petiole $0.8-1.5 \mathrm{~cm}$ long. Inflorescence a dense, subcapitate raceme up to $1-2 \mathrm{~cm}$ long, with 4-12 flowers, shortly overtopping ground level. Bracts widely ovate, apiculate, 9-18 $\times 4-15 \mathrm{~mm}$, green with membranous, white margins and base, glabrous, entire. Pedicels at anthesis $10-14 \mathrm{~mm}$ long. Flowers shortly tubular, slightly widening at the end of the tube. Perigone pale yellow to cream in colour, free segments 4-6 $\times 3-3.5 \mathrm{~mm}$, green with purple flush and with white membranous margins, at first straight and erect in bud, later spreading and patent and finally strongly reflexed with a sigmoid curve at the base at anthesis; perigone-filaments tube 5-7 $\times 3-4 \mathrm{~mm}$, subcylindrical at the base and widening at the upper portion into a funnel that exposes the gynoecium. Filaments thickened, attenuate, erect to slightly incurved-arcuate, white to pale yellow with a reddish tinge, purple-reddish at the base, 3-5 mm long, connate at the base for ca. 1-1.5 mm above the perigone; anthers oblong, yellow-green with a reddish flush, ca. $2.5-3 \times 1.5 \mathrm{~mm}$ when closed, dorsifixed, with yellow pollen. Ovary sub-oblong, green with a reddish flush, $4-5 \times 3.5-4 \mathrm{~mm}$, truncate to the style. Style green with a reddish flush, suberect, differentiated from the ovary, gradually tapering to the apex, $12-13 \mathrm{~mm}$ long at anthesis, bent at the apex in bud. Capsule ovate, 7-12 $\times 4-9 \mathrm{~mm}$. Seeds globose, apiculate, black, $1.1-1.3 \times 0.8-1.1 \mathrm{~mm}$, smooth or slightly rugose. Figs. 2, 3a, 4a, 5a.

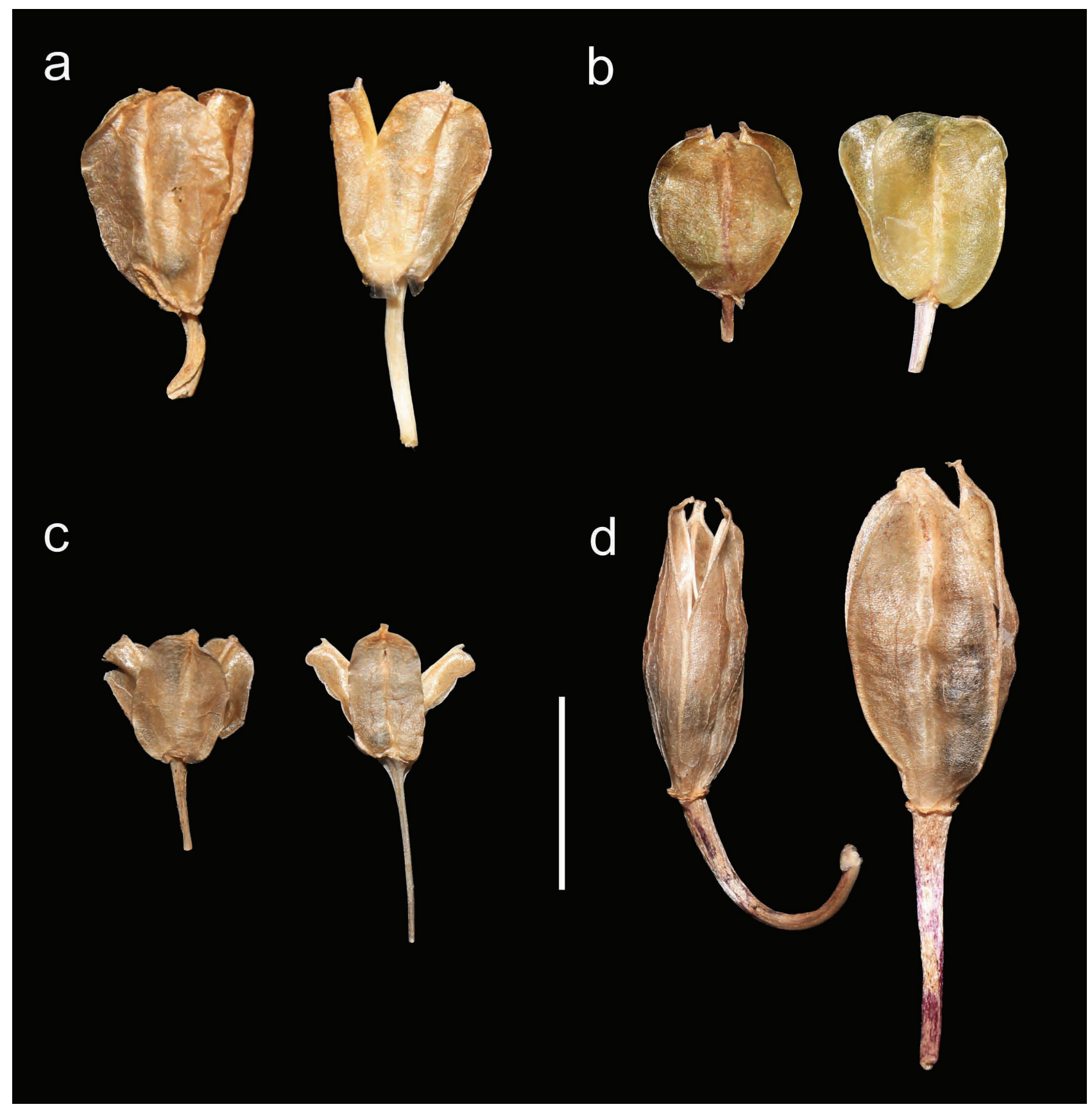

FIGURE 3. Comparison of capsules in lateral view of Massonia echinata L.f. (a), M. latebrosa Masson ex Baker (b), M. tenella Sol. ex Baker (c) and M. pseudoechinata Mart.-Azorín et al. (d). Scale bar $1 \mathrm{~cm}$. 
Etymology:- The species was named after the rough surface of its leaves, covered with cone-like emergences topped by a conical trichome (echinatus, $-a,-u m$ : rough, scabrous, prickly).

Phenology:-Massonia echinata flowers from August to September in the wild and fruits appear from late September to October.

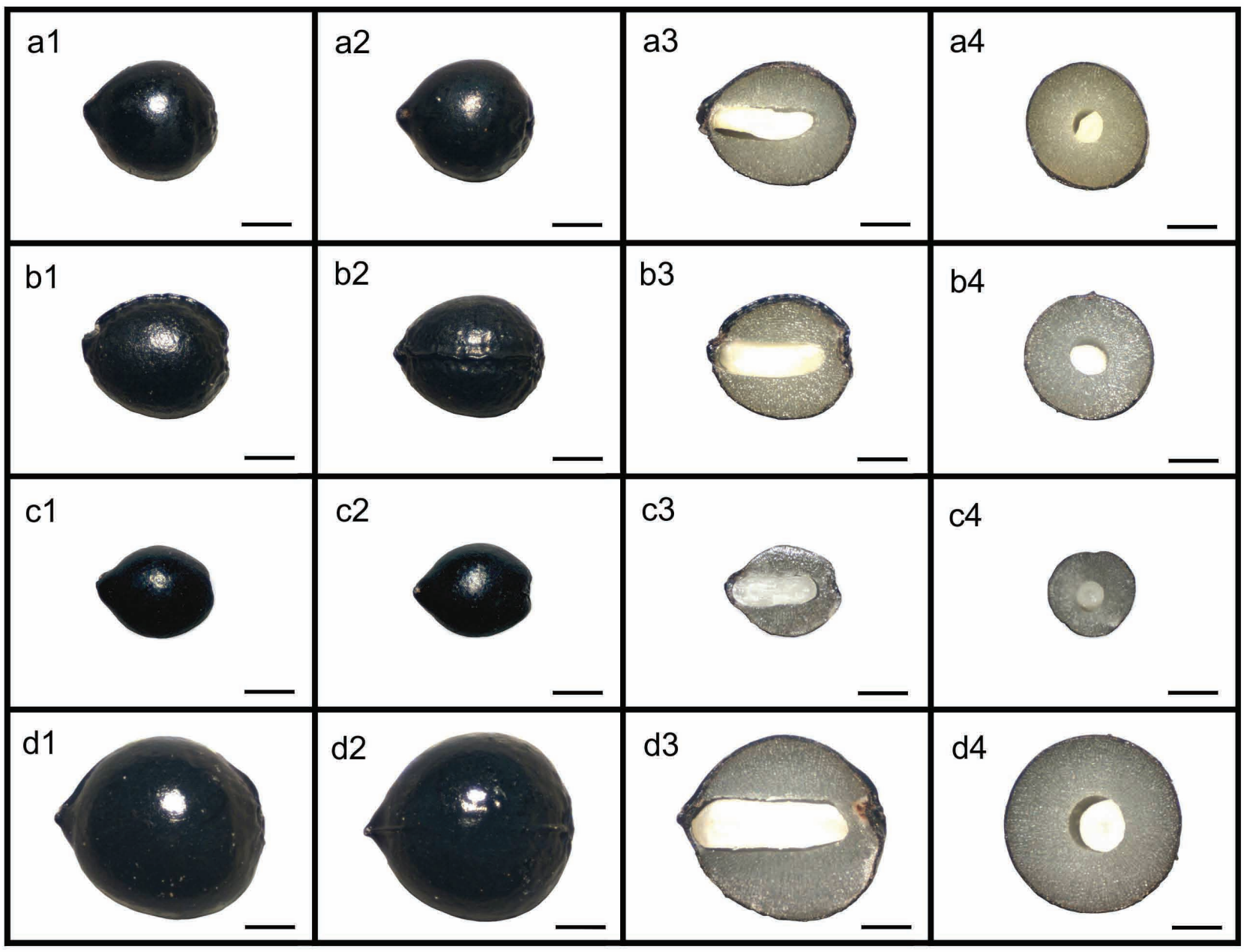

FIGURE 4. Comparison of seeds of Massonia echinata L.f. (a), M. latebrosa Masson ex Baker (b), M. tenella Sol. ex Baker (c) and M. pseudoechinata Mart.-Azorín et al. (d). 1. lateral view; 2. Raphal view; 3. longitudinal section; 4. Transversal section. Scale bar: 0.5 $\mathrm{mm}$.

Habitat:-Massonia echinata is mostly found in rocky habitats (sandstone outcrops) between 600 and $900 \mathrm{~m}$ in elevation, in vegetation types known as Bokkeveld Sandstone Fynbos (FFs1) and Vanrhynsdorp Shale Renosterveld (FRs1) (both belonging to Fynbos Biome), characterised by winter rainfall peaking from May to August, with a mean annual precipitation of $290 \mathrm{~mm}$ and 3-10 days of frost per year (Mucina \& Rutherford 2006).

Distribution:- This species is known to us from Oorlogskloof and its surroundings on the Bokkeveld Plateau, southwest of Nieuwoudtville (Fig. 6).

Taxonomic relationships:-Massonia echinata can be easily distinguished by the relatively small leaves covered by distinct conical emergences with a declined trichome on top bearing a smooth surface; perigone-filaments tube 5-7 mm long, subcylindrical at the base and widening at the upper portion into a funnel that exposes the gynoecium; free portion of perigone segments at anthesis strongly reflexed with a sigmoid, but not strongly inrolled, curve at the base; filaments reddish and basally connate for ca. $1-1.5 \mathrm{~mm}$ above the perigone; and ovary sub-oblong, green with a reddish flush, truncate to the style. Massonia echinata is related to M. latebrosa based on flower morphology, but the latter differs by the leaves bearing longitudinal, purplish maculae and spheroidal to ellipsoidal trichomes, and the allopatric distribution (Table 1, Fig. 6). Both species may be related to the Massonia depressa species complex based on the flower morphology, but they differ by distinct vegetative characters and the size of the flowers. 


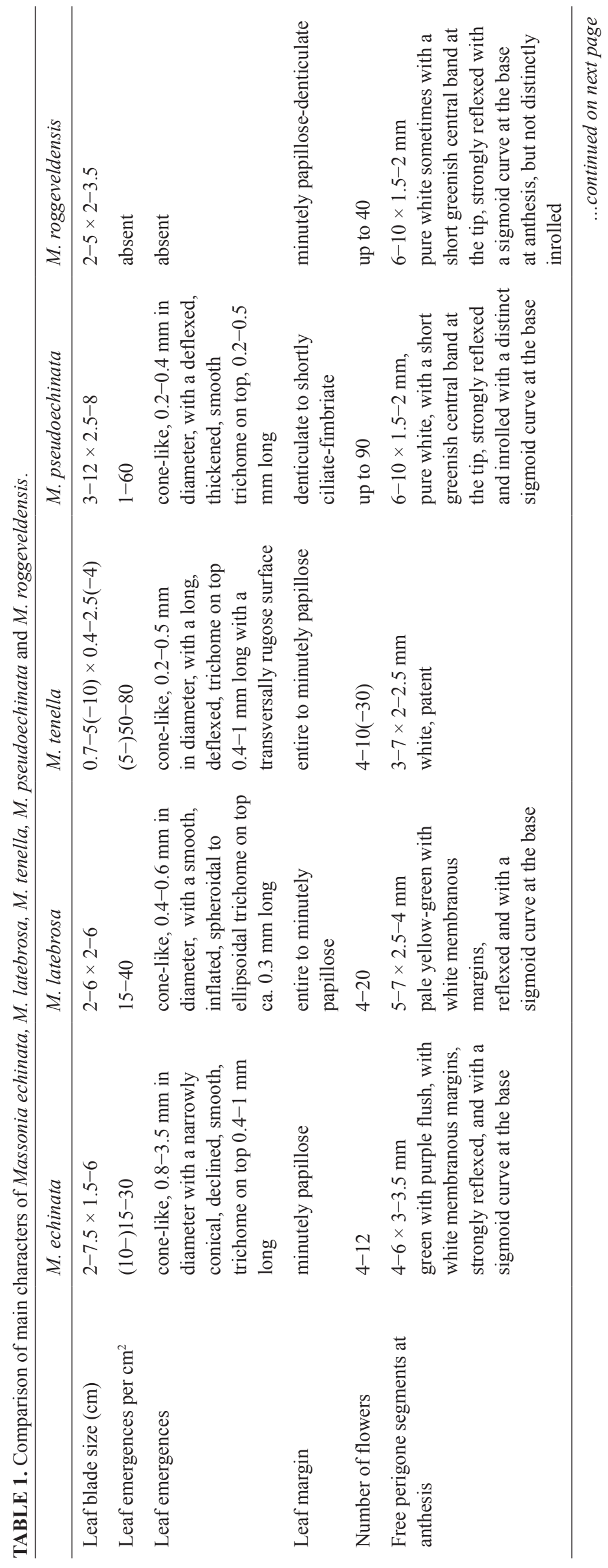




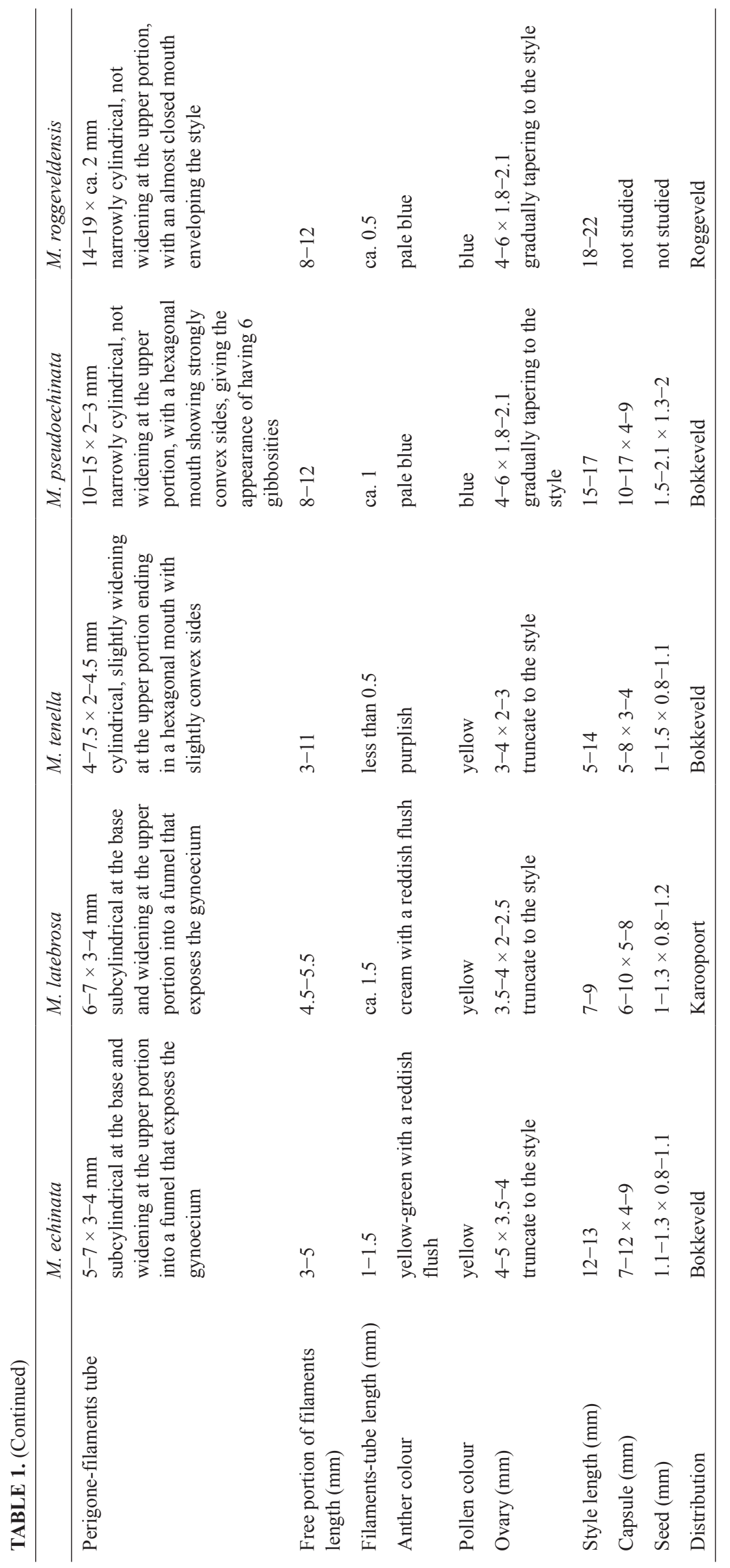



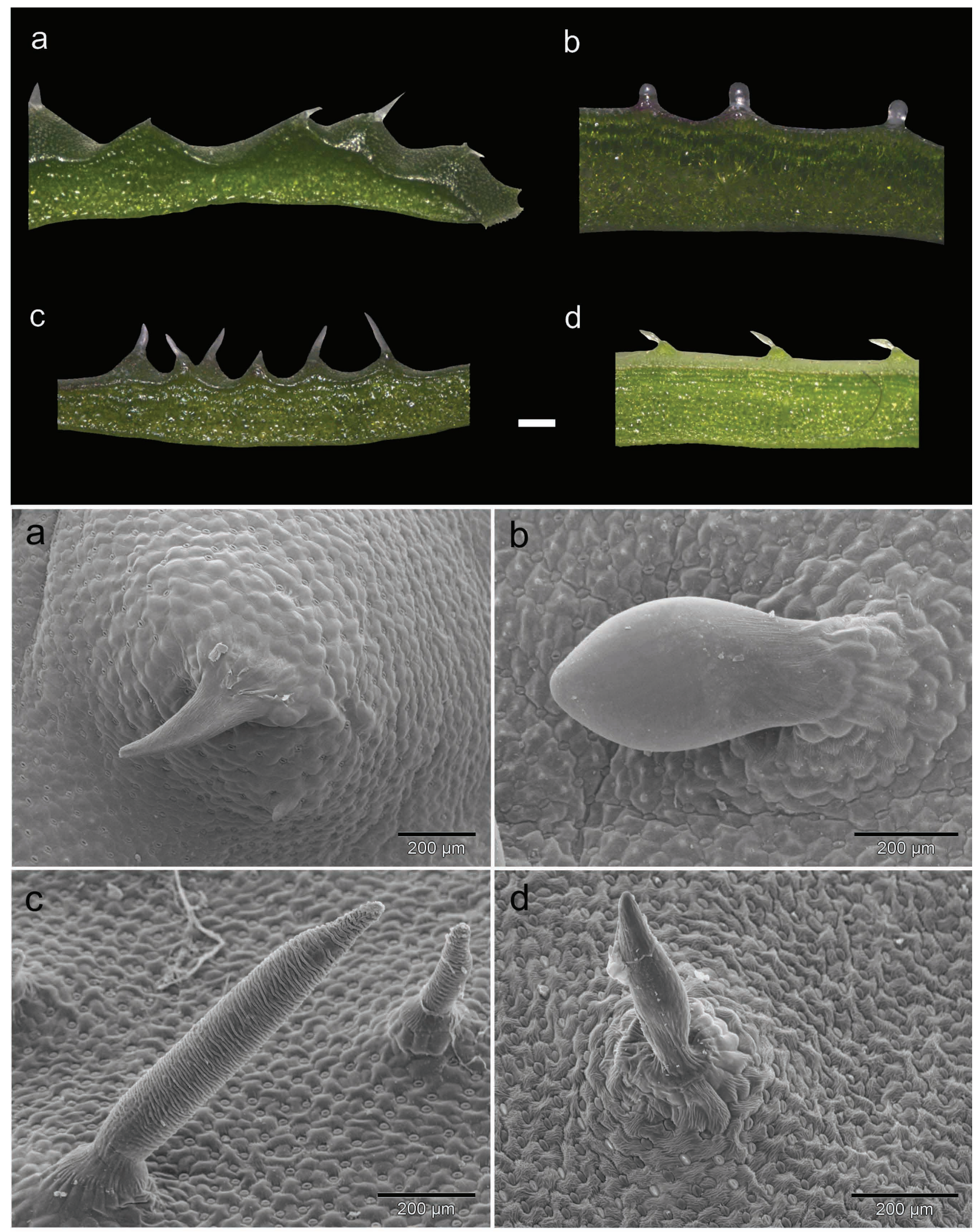

FIGURE 5. Comparison of leaf emergences of Massonia echinata L.f. (a), M. latebrosa Masson ex Baker (b), M. tenella Sol. ex Baker (c) and M. pseudoechinata Mart.-Azorín et al. (d). Light microscope images above (scale bar: $0.5 \mathrm{~mm}$ ) and SEM images below (scale bar: $200 \mu \mathrm{m})$.

Additional specimens studied:-SOUTH AFRICA. Northern Cape. Calvinia (3119): Van Rhynsdorp Div., Nieuwoudtville (-AC), August 1931, fld. In hort. L. Bolus, L. Bolus s.n. (BOL61541!); Calvinia (3119): Nieuwoudtville, Uitkoms farm (-AC or -CA), 820 m elevation, 9 August 1983, C.M. van Wyk 1369 (NBG!, PRE0712822-0!); Calvinia 
(3119): Nieuwoudtville, Oorlogskloof Nature Reserve (-AC), $697 \mathrm{~m}$ elevation, 15 August 2001, W.A.J. Pretorius 741 (K!, MO5887658!, NBG181439!, PRE!); Calvinia (3119): Nieuwoudtville, Oorlogskloof Nature Reserve (-AC), 697 m elevation, 20 August 2013, WW04916 (GZU photo!); Calvinia (3119): Oorlogskloof hiking trail (-AC), $738 \mathrm{~m}$ elevation, 20 August 2012, C. Merry (iSpot photo!, http://www.ispotnature.org/node/486371?nav=parent_ob).

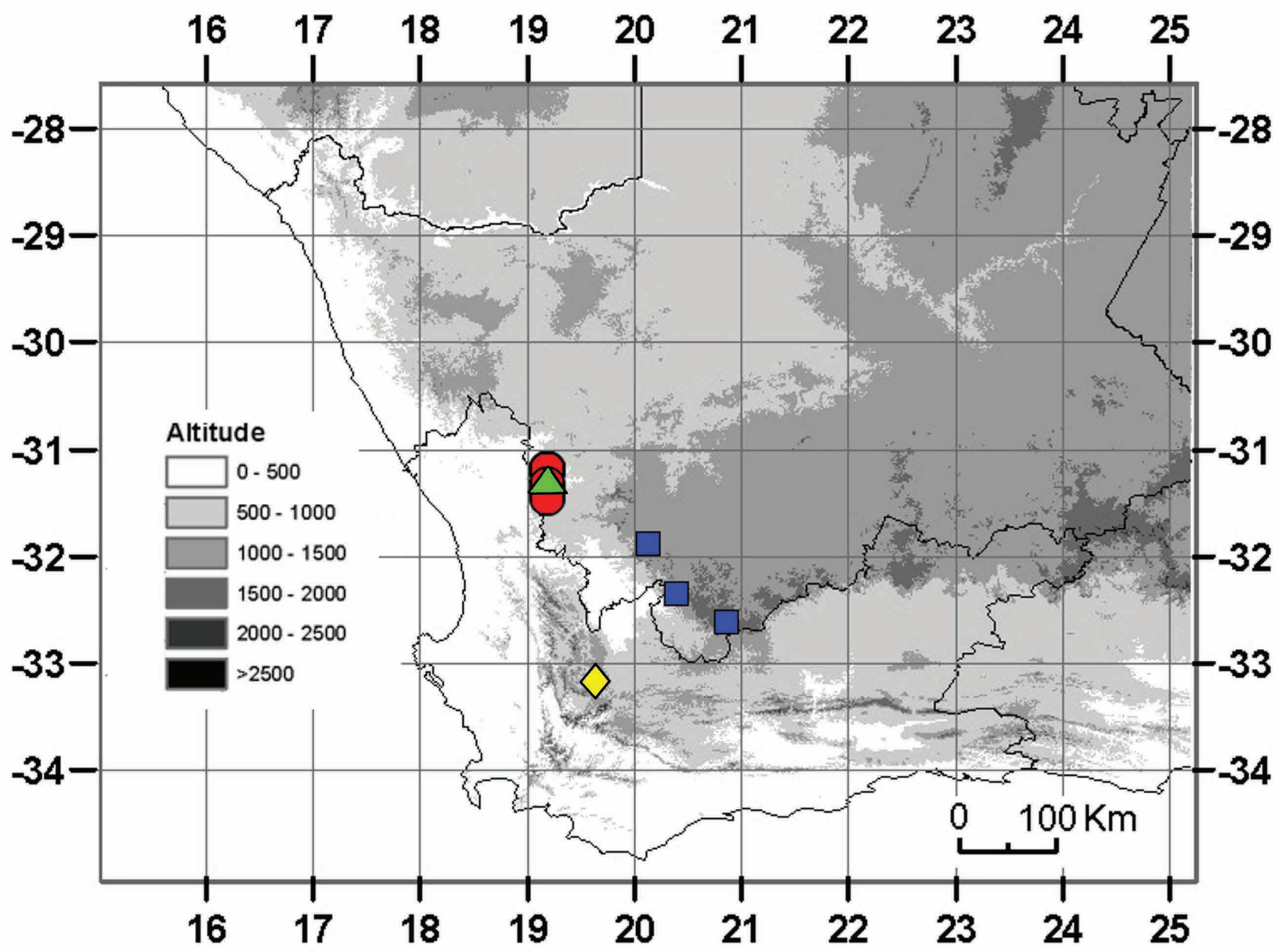

FIGURE 6. Known distribution of Massonia echinata L.f. and M. pseudoechinata Mart.-Azorín et al. (both green triangle), M. latebrosa Masson ex Baker (yellow diamond), Massonia tenella Sol. ex Baker (red circle), and M. roggeveldensis Mart.-Azorín et al. (blue square).

\section{The case of Massonia latebrosa}

Masson's second visit to the Cape took place between $10^{\text {th }}$ of January 1786 and March 1795 . The details of this trip have been poorly documented, as commented by Gunn \& Codd (1981) and Glen \& Germishuizen (2010).

On 21 March 1793 Masson wrote in a letter to Thunberg: "I however broke through my orders and made one journey to the Namaqua Land and another to the Kleijn Roggeveld and Zwarteberg which proved productive to many beautiful plants" (Karsten 1959: 301). In the same letter he also reported on his new findings: "of the Genus Massonia I have discovered four new Species".

As commented by Karsten (1959) and Forbes (1965), Masson left the Cape early in August 1792 towards the Klein Roggeveld, passing the Bokkeveld, which accords with the information given in Masson's drawing No. 115 (Fig. 7a) named Massonia latebrosa and kept at BM, reading as follows: "F. Masson pinxt [pinxit?] / C. B. S. august 1792", "Massonia latebrosa", "Hab. in Speluncae Bokefeld / Fl. in Hort. Massoniana" (Transl.: ... Habitat in caves in the Bokkeveld. Flowered in Garden ...) and "antherae \& stam. / made finer". A later hand wrote "Massonia latebrosa Masson! Journ. Bot. 1886, 336". In this respect, Karsten (1959) commented that "the sketch appears to have been made by Masson of the collected plant when it flowered in his garden in Cape Town" and that "the habitat as given by Masson sounds a bit strange. But Miss Barker writes that she has seen Massonias growing at the base of the overhanging rocks, which could pass as caverns. The name Masson has given to this "mystery species" is very appropriate, as it refers to its way of growing: "latebros" means "hidden"". 
The Bokkeveld is a very broad geographic concept since several regions of the Cape has been called 'Bokkeveld', spanning Tulbagh in the south to Nieuwoudtville in the north. It is subdivided into the Koue (cold), Onder (lower), Oude (old) and Warm Bokkeveld (Raper 1987: 55). Therefore, it seems that Masson, during his second trip to the Cape, visited the southern areas of the Bokkeveld (Warm Bokkeveld) - according to Forbes (1965)—in August 1792 and later travelled to the Klein Roggeveld. On this journey, Masson most likely passed through the natural pass currently known as Karoopoort, located about $40 \mathrm{~km}$ north-east of Ceres on the way to Sutherland.
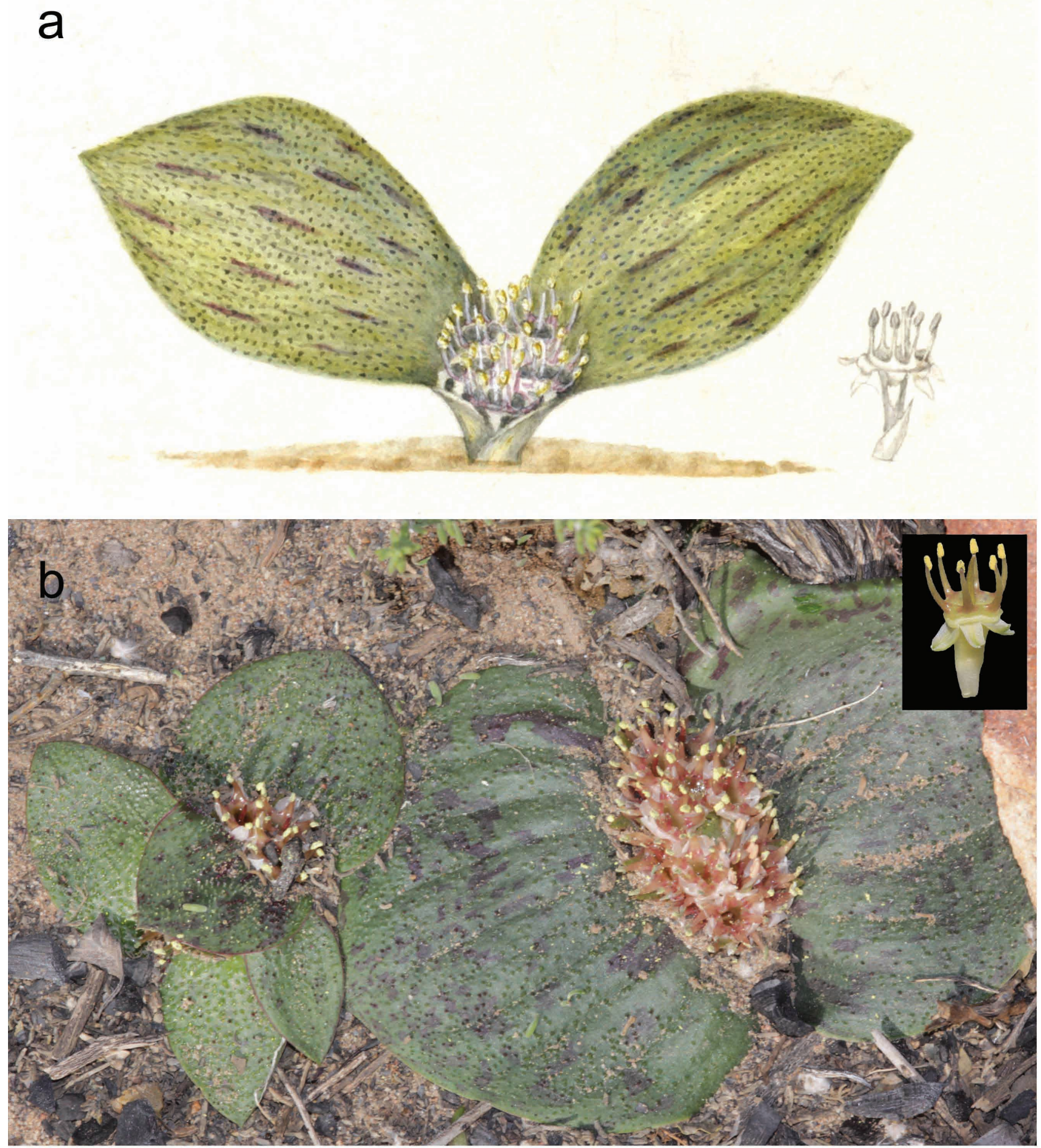

FIGURE 7. Massonia latebrosa Masson ex Baker. a. Holotype of M. latebrosa Masson ex Baker (drawing by F. Masson no. 115 kept at $\mathrm{BM})$. b. Plants in flower in the wild at Karoopoort (corresponding to WW04921). Individual flower shown on top right inset.

Baker (1886) described Massonia latebrosa Masson ex Baker citing the following characters: "Leaves oblong or obovate, erecto-patent, $2-2 \frac{1}{2}$ in. [ca. 5-6 cm] long, 1-1 1/4 in. [ca. 2.5-3 cm] broad, acute, scabrous, and streaked vertically with purple. Capitulum sessile, under an inch in diam. Flowers white; bracts lanceolate; tube cylindrical, 
1/3-1/2 in. [ca. $8-12 \mathrm{~mm}$ ] long, $1 / 8$ in. [ca. $3 \mathrm{~mm}$ ] diam at the throat; segments lanceolate, reflexing, $1 / 6 \mathrm{in}$. [ca. $4 \mathrm{~mm}$ ] long. Stamens erect, $1 / 4$ in. [ca. 6 mm] long, connate in a ring at the base. Hab. Bokefeld, Aug. 1792, Masson". Baker (1897) in Flora Capensis transcribed the cited description for M. latebrosa, but added "Described from a drawing at the British Museum" and Jessop (1976) and Müller-Doblies \& Müller-Doblies (2010) cited the drawing of M. latebrosa kept at BM (Fig. 7a) as the holotype of the species.

The illustration by Masson includes a plant in flower and a flower with a bract on the right-hand side (Fig. 7a). The depicted plant shows green, pustulate leaves with longitudinal, purplish maculae, an inflorescence with about six flowers, and flowers with a wide mouth of the perigone-filaments tube, strongly reflexed free portion of perigone segments, which has a sigmoid curve at the base, a purplish filaments tube and yellow anthers. However, some important diagnostic characters are not elaborated upon, perhaps leading to the misinterpretation of this species.

Jessop (1976), van der Merwe (2002) and Summerfield (2004) included M. latebrosa in the synonymy of M. echinata and Jessop (1976) commented that "a Masson specimen, without locality, in G matches the BM drawing" referring to M. latebrosa.

Recently, Müller-Doblies \& Müller-Doblies (2010) included M. latebrosa in the synonymy of M. tenella, despite the fact that the drawings of both species made by Masson and kept at BM show obviously different plants (Figs. 7a, 9a). Manning \& Goldblatt $(2003,2012,2013)$ did not mention M. latebrosa.

Study of living plants of a Massonia from Karoopoort (Fig. 7b, 8) demonstrates that M. latebrosa represents a distinct species based on clear morphological characters, as shown below. In general terms, M. latebrosa shares its flower morphology with M. echinata, but it differs by the leaves, which are vertically streaked with purple and show smaller, wart-like emergences, among other characters, and in its distribution.

\section{Massonia latebrosa Masson ex Baker (1886: 336)}

Type:-SOUTH AFRICA. Western Cape. Hab. in Speluncae Bokefeld; August 1792, F. Masson s.n. (holotype drawing number 115 kept at BM!, Fig. 7a). Epitype (here designated):-Worcester (3319): Ceres Div., Karoo Poort (-BA), hills, 27 July 1941, E. Esterhuysen 5478 (BOL61546!). Note:-As the holotype lacks some important diagnostic characters, for instance the leaf indumentum, an epitype has been selected here for purpose of avoiding further misidentifications.

Deciduous geophyte. Bulb ovoid to subglobose, $0.8-1.5 \times 0.8-1.5 \mathrm{~cm}$, with white fleshy bulb scales, covered by papery, purplish inner tunics and brown outer tunics. Leaves 2, synanthous, opposite, appressed to the ground, from narrowly ovoid and acute in young plants to broadly elliptical (wider than long), in older plants, with an acute to obtuse apex, limb 2-6 $\times 2-6 \mathrm{~cm}$, with a short apicule about $2 \mathrm{~mm}$ long, with entire to minutely papillose margins; adaxial side green, streaked longitudinally with purple, with 15-40 symmetrical, cone-like emergences per $\mathrm{cm}^{2}$, which are $0.4-0.6 \mathrm{~mm}$ in diameter, with a smooth, inflated, spheroidal to ellipsoidal trichome on top (ca. $0.3 \mathrm{~mm}$ long); abaxial side smooth, green; petiole $0.5-1.5 \mathrm{~cm}$ long. Inflorescence a dense, subcapitate raceme up to $1.5-2 \mathrm{~cm}$ long, with 4-20 flowers, shortly overtopping ground level. Bracts ovate-lanceolate, 13-28 $\times(4-) 6-15 \mathrm{~mm}$, green with white membranous margins and base, glabrous, entire. Pedicels of flowers at anthesis $2.5-9 \mathrm{~mm}$ long. Flowers shortly tubular, slightly widening at the apex of the tube. Perigone pale yellow to cream in colour; free segments 5-7 $\times$ 2.5-4 mm, pale yellow-green with white membranous margins, at first straight and erect in bud, later spreading and patent and ultimately reflexed with a sigmoid curve at the base at anthesis; perigone-filaments tube 6-7 $\times 3-4 \mathrm{~mm}$, subcylindrical at the base and widening at the upper portion into a funnel that exposes the gynoecium. Filaments thickened, attenuate, erect to slightly incurved-arcuate, pale yellow with red flush to red, purple-reddish at the base, 4.5-5.5 mm long, connate at the base for ca. $1.5 \mathrm{~mm}$ above the perigone; anthers oblong, cream with a reddish flush, ca. $3 \times 1.5 \mathrm{~mm}$ long when closed, dorsifixed, with yellow pollen. Ovary suboblong, pale yellow to greenish, 3.5-4 $\times$ 2-2.5 mm, truncate to the style. Style pale green to red, suberect, differentiated from the ovary, gradually tapering to the apex, 7-9 mm long at anthesis, with a bend at the apex when in bud. Capsule ovate to oblong, 6-10 $\times 5-8 \mathrm{~mm}$. Seeds globose, apiculate, black, $1-1.3 \times 0.8-1.2 \mathrm{~mm}$, smooth or slightly rugose. Figs. 3b, 4b, 5b, 7 .

Etymology:- Species named after its habitat, hidden in 'caves' or at the base of overhanging rocks and being a "mystery species" that was never found after its description (Karsten 1959) (latebrosus, - a, -um: hidden, retired, secret).

Phenology:-Massonia latebrosa flowers between July and September in the wild.

Habitat:-Massonia latebrosa is found in rocky habitats between 700 and $800 \mathrm{~m}$ in elevation in both Swartruggens Quartzite Fynbos (FFq2) belonging to Fynbos Biome as well as in Swartruggens Quartzite Karoo (SKv2) belonging to Succulent Karoo Biome. The distribution area is characterised by winter rainfall regime and a clear precipitation 
optimum from May to August, with a mean annual precipitation of ca. $260 \mathrm{~mm}$ and 10-20 days of frost per year (Mucina \& Rutherford 2006).

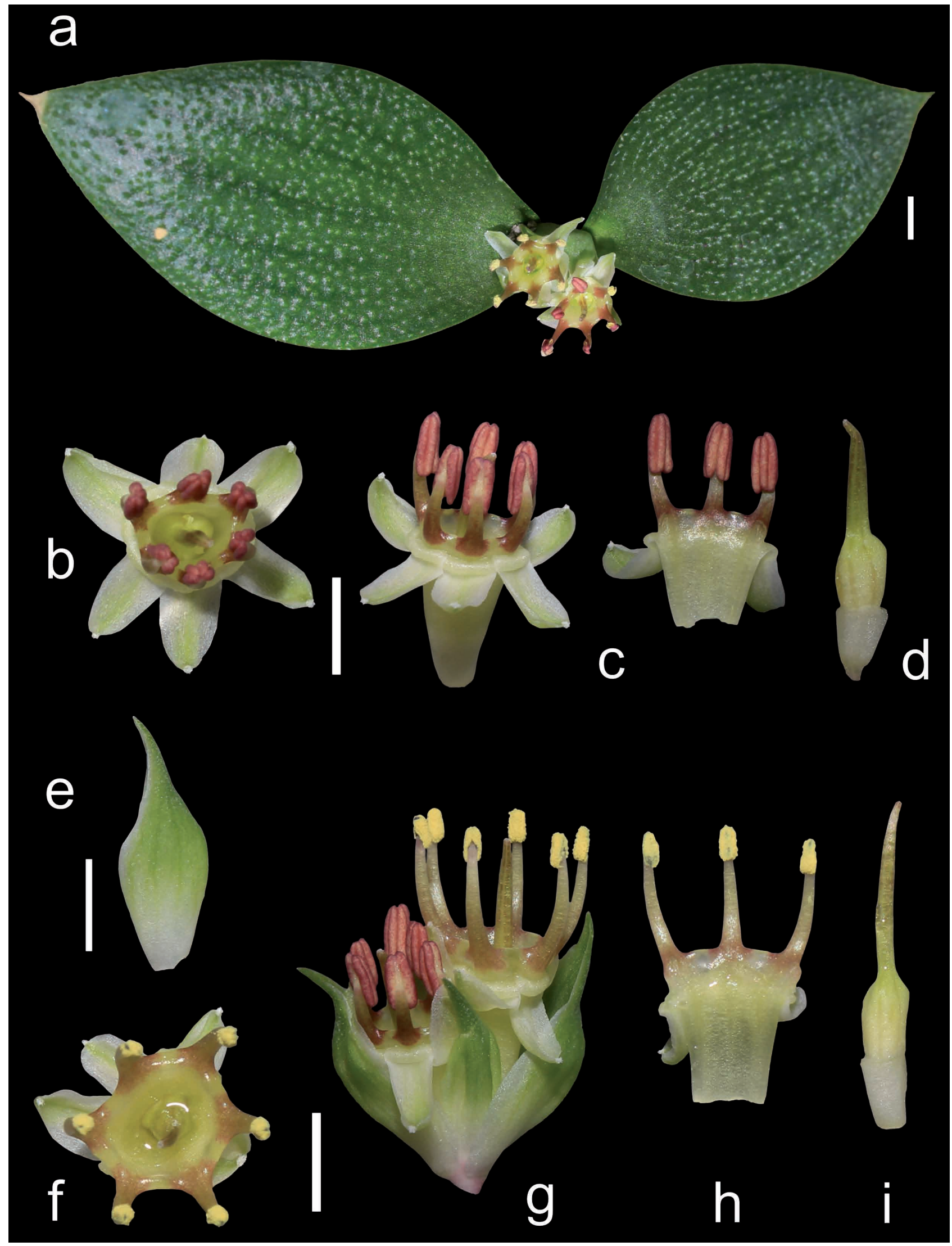

FIGURE 8. Massonia latebrosa Masson ex Baker in cultivation grown from seeds from Karoopoort, Western Cape province, South Africa (corresponding to WW04921). a. Plant in apical view; b. Flower with closed anthers, apical view; c. Flower and dissected flower with closed anthers, lateral views; d. Gynoecium, lateral view; e. Bract, lateral view, abaxial side; f. Flower with open anthers, apical view; g. Inflorescence, lateral view; h. Dissected flower with open anthers, lateral view; i. Gynoecium, lateral views. Scale bars $5 \mathrm{~mm}$. 
Distribution:- - It is only known to us from Karoopoort (Fig. 6).

Taxonomic relationships:-Massonia latebrosa can be distinguished by the leaves streaked longitudinally with purple and covered by inflated, spheroidal to ellipsoidal trichomes bearing a smooth surface (Fig. 5b, 7). Massonia latebrosa is related to M. echinata based on flower morphology, as shown above, but the latter differs by distinct vegetative characters and in distribution (Table 1). The $M$. depressa species complex shows similar flower morphology to M. echinata and M. latebrosa, but the former differs by distinct characters, such as the smooth leaves and the larger flowers.

Further comments:-Baker (1886) described the tube of the flowers of Massonia latebrosa as "Flowers [...] tube cylindrical, 1/3-1/2 in. [ca. 8-12 mm] long" slightly differing from our measurement, being 6-7 mm long. Although the source of the measurement presented by Baker (1886) is uncertain, it could be hypothesized that Baker included the length of the pedicel of the flower into the length of the tube, taken from Masson's painting (Fig. 7a) which does not clearly show the junction between the flower and its pedicel.

Additional specimens studied:-SOUTH AFRICA. Western Cape. Worcester (3319): Ceres C.P., Karoopoort (-BA), 21 September 1944, W.F. Barker 3066 (NBG71206!); Worcester (3319): Ceres C.P., Karoopoort (-BA), 7 August 1945, Kirstenbosch Exp. NBG402/44 (NBG71201!); Worcester (3319): Baviaanshoek, Karoopoort (-BA), 753 m elevation, 3 August 2013, WW04921 (GZU photo!).

\section{The case of Massonia tenella}

Masson, during his second visit to the Cape, made two major excursions into the Kamiesberg region (Karsten 1959). Most probably on his way back from his second visit he collected a plant in the "Buckland" that flowered in his garden at the Cape and that he depicted in July 1794.

Massonia tenella was then described by Baker (1870) as follows: "Folia crasse carnoso-coriacea, lanceolata, acuta, 1 poll. longa, utrinque angusta, petiolata, petiolis scapum arcte cingentibus, supra setis robustis albidis dense vestita [...] Perianthium 4-4 1/2 lin. longum, segmentis lineari-lanceolatis erectis tubo gracili duplo brevioribus. Filamenta lanceolata, vix ultra 1/2 lin. longa. Cap. B. Spei, Masson! Drège, 3509!". Baker (1897) added "Figured in Masson's drawings at the British Museum from a plant obtained in Bokkeland, that flowered in England in July, 1794". As Masson only returned to England in March 1795, this statement appears to be erroneous.

The cited drawing at BM carrying the number 112 (Fig. 9a) shows a plant in flower, and two further flowers, one of them dissected and showing the gynoecium. The plant shows suberect leaves, a typical character of this species when cultivated (Fig. 9c); green leaves that bear emergences with a distinct trichome on top; an inflorescence with few flowers; perigone-filaments tube cylindrical, about as long as the free portions of tepals and filaments; free portion of tepals lanceolate and patent at anthesis, not reflexed; filaments flattened, triangular, erect and very shortly connate at the base; anthers purplish when closed; pollen yellow; ovary ovate, darker than the style and differentiated from the latter, which is erect and narrowly tapers to the minute stigma. Moreover, Masson's drawing bears the following annotation at the bottom: "F. Masson", "Massonia tenella" and "Loco natali Buckland, Fl. in Hort. Massioni Julio 1794". A different handwriting adds below: "See spec. in Herb. Fl. Cap. VI 409 Massonia tenella Baker Journ. Linn. Soc. XI 389".

As commented by Müller-Doblies \& Müller-Doblies (1997), Jessop (1976) did not include the name Massonia tenella in the synonymy of M. echinata, probably by mistake or omission, but cited M. tenella's type under M. huttonii, as both latter taxa have similar type references.

Recently, Müller-Doblies \& Müller-Doblies (1997) reinstated M. tenella exclusively based on the study of herbarium material. They also cited a collection at BM as lectotype of this species and commented: "Baker 1897: 409 mentions that the type plant flowering in England in 1794 was "obtained in Bokkeland = neighbourhood of Vanrhynspas; this information is not on the type sheet but probably on the drawing (BM); the two flower heads on the type sheet are in fruit, thus Masson possibly collected them end of Oct. 1774 when Thunberg collected Massonia echinata on their third common expedition". We can confirm that the information on the locality of M. tenella given by Baker (1897) is on the drawing no. $112 \mathrm{kept}$ at BM (Fig. 11a), as detailed above. However, a single Massonia collection by Masson exists at BM named Massonia echinata, but there is no locality information or any annotations suggesting that it has ever been determined as Massonia tenella (J. Gregson, pers. comm.). Therefore, the cited herbarium collection at BM does not represent the original material of $M$. tenella and is therefore not suitable for typification. Müller-Doblies \& Müller-Doblies (2010) included $M$. latebros $a$ as a new synonym for $M$. tenella, a step we do not follow considering the clear floral differences between the two species (Figures 7a, 9a). 
a
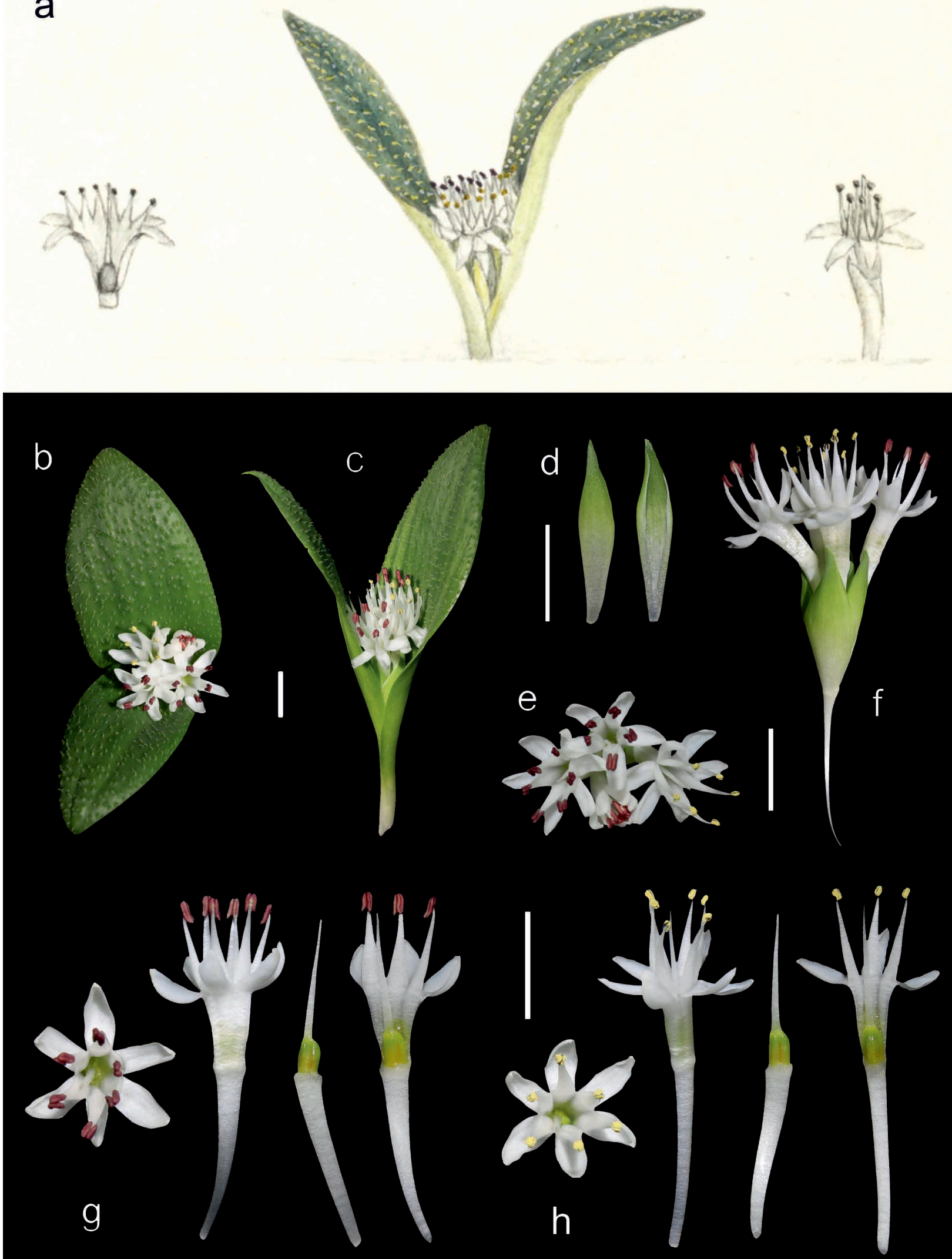

FIGURE 9. Massonia tenella Sol. ex Baker. a. Lectotype of M. tenella (drawing by F. Masson no. 112 kept at BM). b-h. Plants in flower in cultivation from south of Nieuwoudtville, Northern Cape province, South Africa (corresponding to WW01145). b. Plant in flower, apical view; c. Plant in flower, lateral view; d. Bracts, lateral view; e. Inflorescence, apical view; f. Inflorescence, lateral view; g. Flower and dissected flower with closed anthers, apical and lateral views; h. Flower and dissected flower with open anthers, apical and lateral views. Scale bars $1 \mathrm{~cm}$. 
Müller-Doblies \& Müller-Doblies (1997) commented on M. tenella that "no other Massonia has such short filaments being 1-2 mm long as indicated by Baker $(1870,1897)$ although the lectotype at BM [see comments above] shows free filaments $2.2-2.5 \mathrm{~mm}$ long, that together with the filament tube are about $3 \mathrm{~mm}$ long". Furthermore, Müller-Doblies \& Müller-Doblies (1997) included M. bokkeveldiana Poellnitz (1946: 384), originally collected by Schlechter at Oorlogskloof, near Vanrhynspas, in the synonymy of $M$. tenella, and commented that the filaments in the type of this species are 3.5-4.2 mm long. Our observations show that M. tenella bears filaments 3-11 mm long, being slightly variable depending on the specimen studied. The short filaments as described in the original description of M. tenella most probably refer to the collection Drège 3509 studied by Baker and later designated as the type of $M$. wittebergensis Müller-Doblies \& Müller-Doblies (2010: 129), a distinct species restricted to the Drakensberg that was recently accepted by Wetschnig et al. (2014) and Martínez-Azorín et al. (2014b) and which does possess filaments 1.5-2 mm long. However, Müller-Doblies \& Müller-Doblies (2010) paradoxically considered, on the same page of their work, the collection Drège 3509 as both 'paratype' of M. tenella and holotype of M. wittebergensis.

Manning \& Goldblatt (2003) did not mention M. tenella, but Manning \& Goldblatt (2012) followed MüllerDoblies \& Müller-Doblies (1997) and accepted this species, including M. bokkeveldiana as a synonym.

Study of several living and herbarium collections of Massonia from the surroundings of Vanrhyns Pass and Oorlogskloof reveals that M. tenella displays a distinct syndrome of morphological characters (Fig. 9b-h) that allows its acceptance as a species in its own right, as shown below.

\section{Massonia tenella Sol. ex Baker (1870: 389)}

Type (lectotype, here designated):-SOUTH AFRICA. [Northern Cape]: Loco natali Buckland, Fl. in Hort. Massioni Julio 1794, Masson s.n. (drawing number 112 BM!). Epitype (here designated):-SOUTH AFRICA. Northern Cape. Calvinia (3119): 4 km south of Nieuwoudtville (-AC), ca. 720 m elevation, 1987, WW1145 (GZU!). Note:-As the lectotype lacks details on leaf indumentum, an epitype is designated to ensure identification of the species.

= Massonia bokkeveldiana Poellnitz (1946: 384). Type:-SOUTH AFRICA. Northern Cape. 3119 (Calvinia): Onder Bokkeveld, Oorlogskloof, 2200 feet elevation, 21 August 1897, Schlechter 10935 (holotype WRSL; isotypes BOL, BR, E00703130!, G00420207!, GRA!, K000257131!, K000257132!, L, MO2142634!, S15-24614!, US553018!, Z; list of isotypes from Müller-Doblies \& MüllerDoblies 1997).

Deciduous geophyte. Bulb ovoid to subglobose, $0.7-1.5 \times 0.6-1.2 \mathrm{~cm}$, with white fleshy bulb scales, covered by papery, purplish, inner tunics and brown, outer tunics. Leaves 2, synanthous, opposite, appressed to the ground, ovoidlanceolate, with an obtuse apex and a short apicule $<0.5 \mathrm{~mm}$ long, limb 0.7-5(-10) $\times 0.4-2.5(-4) \mathrm{cm}$, with entire to minutely papillose margins; adaxial side green, rarely smooth but usually with (5-)50-80 symmetrical, cone-like emergences per $\mathrm{cm}^{2}, 0.2-0.5 \mathrm{~mm}$ in diameter with a long, deflexed, trichome on top, $0.4-1 \mathrm{~mm}$ long with a transversally rugose surface; abaxial side smooth, green; petiole $0.3-4 \mathrm{~cm}$ long. Inflorescence a dense, subcapitate raceme up to 1.5-2 cm long, with 4-10(-30) flowers, shortly overtopping ground level. Bracts narrowly lanceolate, 7-20 $\times 4-7$ $\mathrm{mm}$, green with membranous white margins and base, glabrous, entire. Pedicels at anthesis 11-18 $\mathrm{mm}$ long. Flowers tubular, slightly widening at the end of the tube. Perigone pure white, rarely with a pink flush when old; free segments 3-7 $\times 2-2.5 \mathrm{~mm}$, white, at first straight and erect in bud, later spreading and finally patent at anthesis, never reflexed; perigone-filaments tube $4-7.5 \times 2-4.5 \mathrm{~mm}$, cylindrical, slightly widening at the upper portion and ending in a hexagonal mouth with slightly convex sides, the ovary included in the tube, not exposed. Filaments triangular, erect, pure white, 3-11 mm long, connate at the base for less than $0.5 \mathrm{~mm}$ above the perianth segments; anthers oblong, purplish, ca. $1.8-2.3 \times 0.8-1.2 \mathrm{~mm}$ when closed, dorsifixed, with yellow pollen. Ovary oblong, green, $3-4 \times 2-3 \mathrm{~mm}$, truncate to the style. Style white, slender, erect, differentiated from the ovary, 5-14 $\mathrm{mm}$ long at anthesis. Capsule ovate-oblong, 5-8 × 3-4 mm. Seeds globose, apiculate, black, 1-1.5 ×0.8-1.1 mm, smooth. Figs. 3c, 4c, 5c, 9 .

Etymology:- Species named after the delicate aspect of all its parts, particularly the flowers (tenellus, - $a,-$ um: tender, delicate).

Phenology:- Massonia tenella flowers from July to August. Fruits appear from September to October.

Habitat:-Massonia tenella is found in shallow sandy pockets on rocky outcrops between 600 and $900 \mathrm{~m}$ in elevation, in vegetation classified as Bokkeveld Sandstone Fynbos (FFs1) and the Vanrhynsdorp Shale Renosterveld (FRs1) in a region characterised by winter rainfall peaking from May to August, with a mean annual precipitation of $290 \mathrm{~mm}$ and 3-10 days of frost per year (Mucina \& Rutherford 2006).

Distribution:-This species is known to us only from the vicinity of Vanrhyns Pass and Oorlogskloof, near Nieuwoudtville (Fig. 6). 
Taxonomic relationships:-Massonia tenella can be easily distinguished by the relatively small leaves, bearing cone-like emergences with a long, deflexed, trichome on top with transversally rugose surface (Fig. 5c); flowers pure white or turning pink when old, with a cylindrical perigone-filaments tube, slightly widening at the apex with a hexagonal mouth and slightly convex sides; free portion of perigone segments patent at anthesis; free portion of filaments triangular, erect, white, and connate for less than $0.5 \mathrm{~mm}$ above the perigone-filaments tube; anthers purplish with yellow pollen; ovary oblong, green; style white, erect; and having small seeds (Figs. 3c, 4c, 9). Regarding the flower morphology, M. tenella shows similarities with $M$. jasminiflora and related species, but it differs by clear vegetative characters and the gynoecium morphology (Table 1) (Martínez-Azorín et al. 2014b). Massonia tenella, $M$. echinata and $M$. latebrosa possess similar bulbs, having purplish papery inner tunics, a link supported by our preliminary phylogenetic results, where these species are placed in the same clade.

Additional specimens studied:- SOUTH AFRICA. Northern Cape. Calvinia (3119): South of Kleinplaas, 'e' areas (-AA), 745 m elevation, 16 August 2014, N. Helme (iSpot photo!, http://www.ispotnature.org/node/601798); Calvinia (3119): Calvinia C.P., Grasberg, Nieuwoudtville (-AC), 5 June 1938, B. Martin sub NBG1557/37 (NBG71203!); Calvinia (3119): Calvinia C.P., Grasberg, Nieuwoudtville (-AC), 4 June 1943, B. Martin sub NBG1557/37 (NBG71202!); Calvinia (3119): Calvinia C.P., Grasberg, Nieuwoudtville (-AC), 20 August 1960, W.F. Barker 9236 (NBG71370!); Calvinia (3119): Grasberg, north west of Nieuwoudtville (-AC), 740 m elevation, 2 September 1984, E.G.H. Oliver 8578 (NBG!); Calvinia (3119): summit of Van Rhyn's Pass (-AC), 11 July 1932, T.M. Salter 2487 (BOL111912!); Calvinia (3119): Van Rhynsdorp Div., top of Van Rhyn's Pass (-AC), 25 July 1941, E. Esterhuysen 5367 (BOL111911!); Calvinia (3119): Vanrhynsdorp C.P., Vanrhyns Pass (-AC), 25 July 1941, R.H. Compton 11167 (NBG71205!); Calvinia (3119): Vanrhynsdorp C.P., summit of Vanrhyns Pass (-AC), 7 June 1956, H. Hall sub NBG227/56 (NBG71204!); Calvinia (3119): Calvinia C.P., Summit of Vanrhyns Pass near Nieuwoudtville (-AC), 12 August 1961, W.F. Barker 9440 (NBG71210!); Calvinia (3119): Calvinia C.P., Top of Vanrhyns Pass near Nieuwoudtville (-AC), 1 June 1962, W.F. Barker 9440 (NBG71209!); Calvinia (3119): Summit of Vanrhynspas (-AC), about 3000 feet elevation, 31 May 1970, H. Hall 3583 (NBG90085!); Calvinia (3119): Summit of Vanrhynspas (-AC), about 3000 feet elevation, 13 June 1970, photos of plants planted in the herbarium garden, H. Hall 3583 (NBG153629!); Calvinia (3119): 4 km south of Nieuwoudtville (-AC), ca. 720 m elevation, 1987, WW01145 (GZU photo!); Calvinia (3119): Nieuwoudtville (-AC), Summerfield 3681 (Cat. 2012) (GZU!); Calvinia (3119): Farm Oorlogskloof (-AC), mainly in fruit, faded flowers white, leaves smooth, 5 August 1998, P. Goldblatt \& J.C. Manning 10961 (MO04881119!); Calvinia (3119): Nieuwoudtville, Oorlogskloof Nature Reserve N22 (-CA), waterlogged soil, loamy, stony soil, flowers white, 669 m elevation, 3 July 2007, W.A.J. Pretorius 728 (MO5887657!, NBG181455!); Calvinia (3119): Nieuwoudtville, Papkuilsfontein, waterfall parking area (-CA), 10 July 1998, B. Orthen s.n. (NBG170003!).

\section{The case of Massonia angustifolia}

Massonia angustifolia was described by Linnaeus (1782), in April of that year, based on Thunberg's notes and collections, as "angustifolia. MASSONIA foliis lanceolato-oblongis glabris. Habitat in Cap. bonae Spei. Thunberg". A herbarium collection kept in the Linnaean herbarium (LINN 414.2!) includes a complete plant in flower (Fig. 10a), and a handwritten annotation at the bottom reads Massonia angustifolia. Moreover, a second collection by Thunberg exists in the Herbarium Alstroemer (S10-14149!), also named Massonia angustifolia, and it includes a single infructescence with large capsules and inconspicuous or removed bracts.

A few months after the description of $M$. angustifolia, Thunberg (1782) validly described M. lanceolata in July of that same year, not being aware of Linnaeus filius's description of his own species. Thunberg (1782) provided a more detailed description as "Spec. 2. Massonia lanceolata: foliis lanceolatis integris glabris. Crescit in summo monte Onderste Roggefeldt. Floret Augusto. Folia Radicalia, pauca, lanceolata, subensiformia, integra, glabra, tripollicaria. [...]". Two collections named M. lanceolata are kept in Thunberg's herbarium (UPS-THUNB7989! and UPS-THUNB7990!) that include in total 7 plants in flower and 3 infructescences (see further comments below).

Study of the type material of Massonia angustifolia and M. lanceolata reveals that both names were based on materials apparently provided by Thunberg, as already indicated by Müller-Doblies \& Müller-Doblies (1997) and Manning \& van der Merwe (2002a) considered as belonging to a single collection. It is not clear if they represent a single collection or specimen.

Jessop (1976) selected the voucher UPS-THUNB7990 (Fig. 10b, c) as the lectotype of M. lanceolata, and later Müller-Doblies \& Müller-Doblies (1997) and Manning \& van der Merwe (2002a) accepted the cited collection as the lectotype of both Massonia angustifolia and M. lanceolata, of which the former name has priority. Moreover, Manning \& van der Merwe (2002a) cited M. lanceolata as a "nomen superfluum" for M. angustifolia and excluded the three infructescences from the lectotype of both names. 

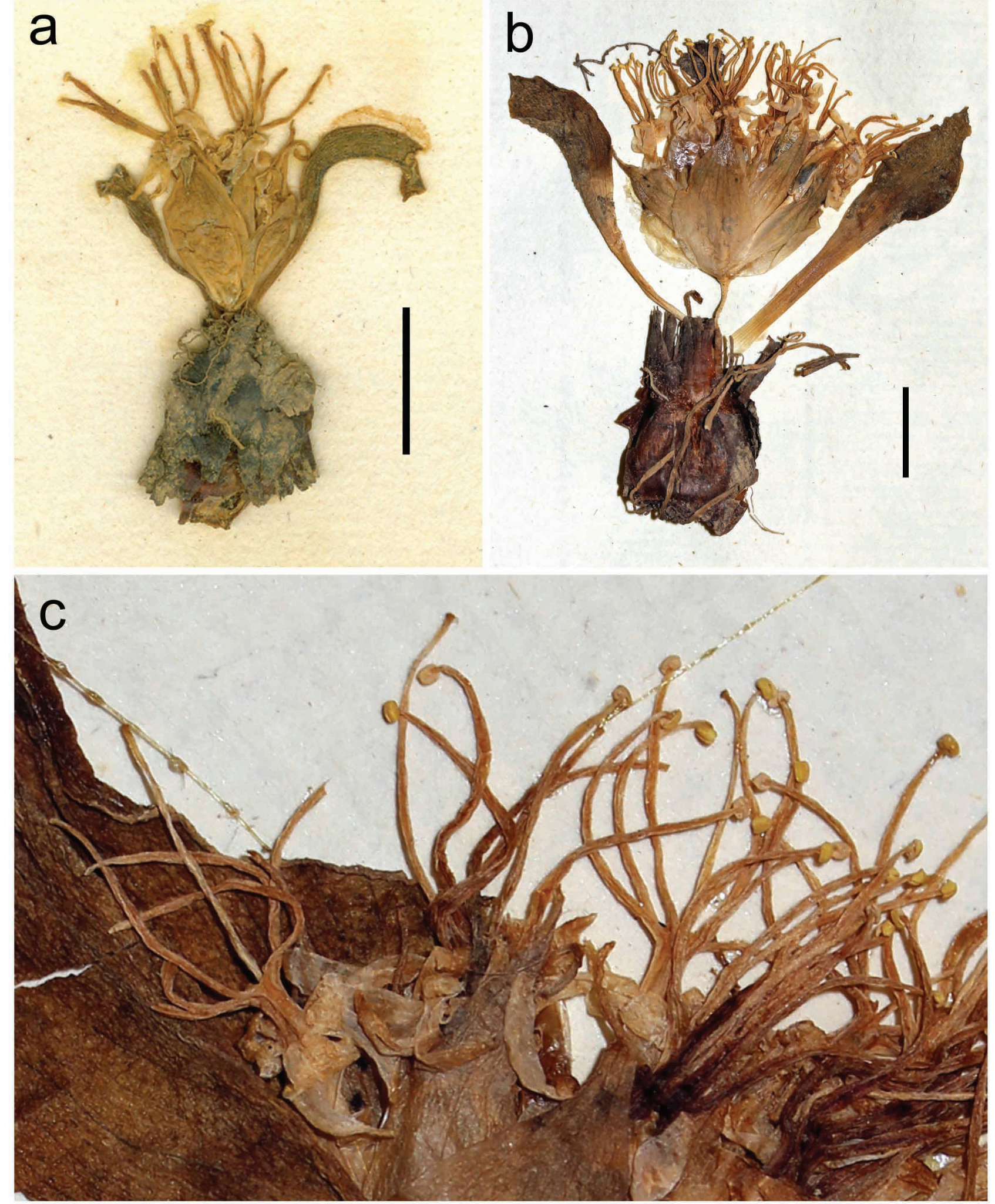

FIGURE 10. Type material of Massonia angustifolia L.f. and M. lanceolata Thunb. a. Lectotype of M. angustifolia (LINN 414.2); b. Lectotype of M. lanceolata, one of the two plants in flower (UPS-THUNB 7990); c. Lectotype of M. lanceolata, detail of flowers showing the filaments distinctly connate above the perigone (UPS-THUNB 7990). Scale bars $1 \mathrm{~cm}$.

However, the collections in Thunberg's herbarium named Massonia lanceolata do not include any direct reference to $M$. angustifolia, and therefore cannot be considered as the original material of the latter species. Therefore, we designate below the collection LINN 414.2, named M. angustifolia and seen by Linnaeus f., as the lectotype of $M$. angustifolia. 
In any case, the flowering plants present in the herbarium vouchers LINN 414.2, UPS-THUNB7989 and UPSTHUNB7990 show the same morphology and represent the same Massonia species. However, the infructescences in the herbarium vouchers S10-14149 and UPS-THUNB7990 most probably correspond to a different species, as suggested by Manning \& van der Merwe (2002a); they might fit well with Daubenya alba A.M. van der Merwe in van der Merwe \& Marais (2002: 308), as can be seen in the capsules illustrated for that species by Manning \& van der Merwe (2002b). Daubenya alba also occurs in the Roggeveld, and this could explain Thunberg's mixed collection in the type material.

Aiton (1789), after studying material Masson sent to Kew, characterised M. angustifolia as "foliis oblongolanceolatis erectis, laciniis corollae reflexis" and "Nat. of the Cape of Good Hope. Mr. Fr. Masson. Introd. 1775. Fl. March and April". He further added an engraving showing a plant in flower with suberect, smooth leaves; wide, lanceolate bracts; flowers with long and narrow perigone-filaments tubes; free portion of tepals reflexed and bearing a sigmoid curve at the base; filaments narrow and spreading, not distinctly connate above the perigone; and ovary ovate with a long, narrow, erect style.

Similarly, Ker Gawler (1804) illustrated M. angustifolia (Fig. 11a), based on the same material sent by Masson in 1775 and used by Aiton (1789), and provided an extended morphological description: "Corolla tubular, twice shorter than pedicels, narrow cylindrical, with its orifice nearly closed by the style and tumid bases of the filaments [...] filaments as long as the tube, campanulately conflex, subsessile, gracilescent [...] Flowers exceeding sweet, smelling something like the common single oriental Hyacinth [...] Found by Thunberg at the Cape of Good Hope on the summit of the Onderste Roggeveld mountain, where it flowers in August; with us in January. Brought over by Masson in 1775" and the colour illustration (Ker Gawler 1804: tab. 763, Fig. 11a), shows flowers with long and narrow tubes; reflexed free portion of tepals, but not showing a strong sigmoid curve at the base; spreading filaments that are shortly connate above the perigone; and blue anthers. This latter illustration broadly coincides with Aiton's engraving for the main morphological characters (Manning \& van der Merwe 2002a: 63).
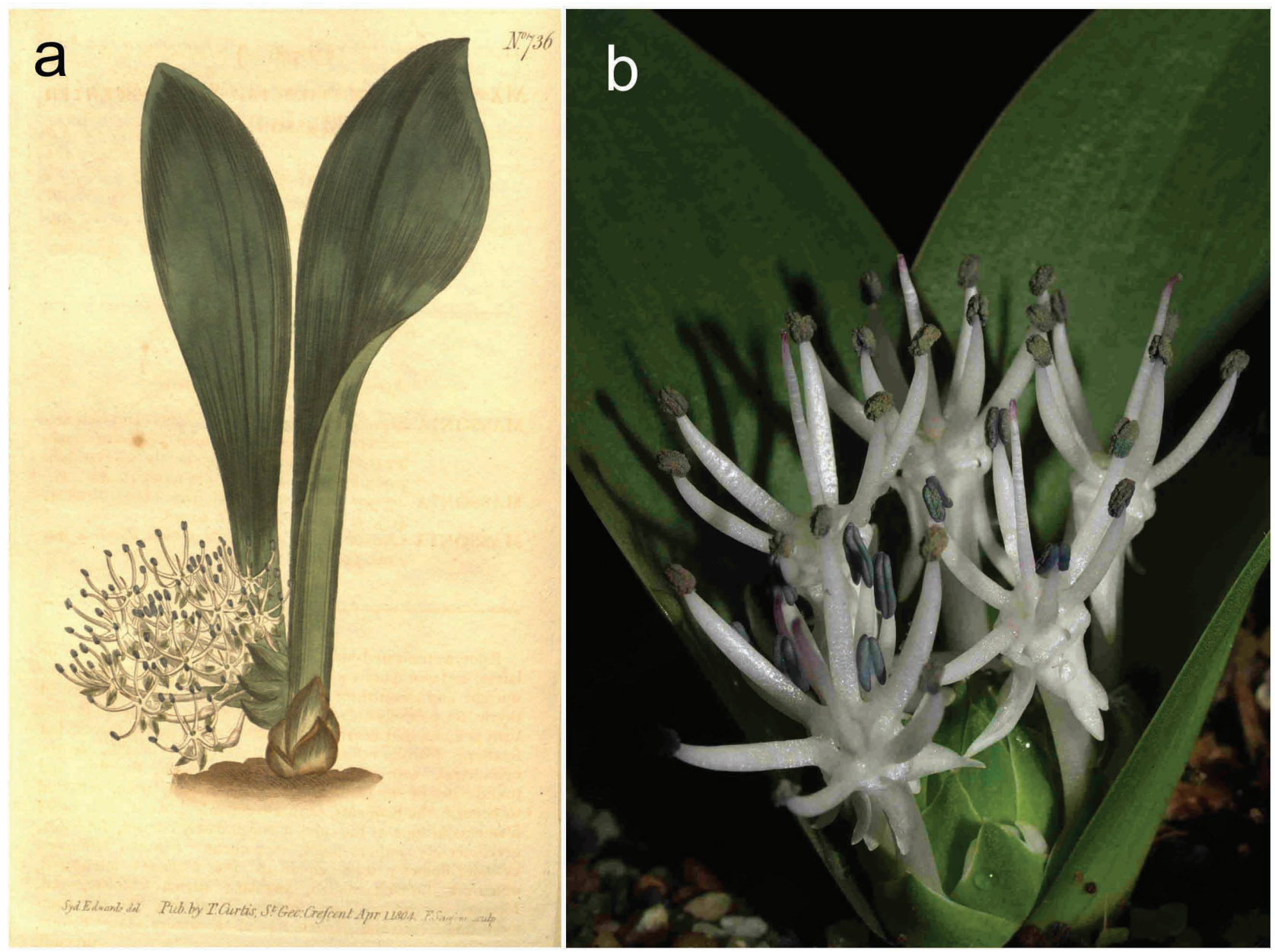

FIGURE 11. Massonia roggeveldensis Mart.-Azorín et al. a. Drawing of M. roggeveldensis Mart.-Azorín et al. by Ker Gawler (1804) under the name M. angustifolia. b. Plants in flower in cultivation from near Middelpos, Roggeveld, Northern Cape Province, South Africa (corresponding to G.C. Summerfield 2506). 
Massonia angustifolia was later accepted by Aiton (1811), Kunth (1843), Baker (1870), Jessop (1976), MüllerDoblies \& Müller-Doblies (1997) and Goldblatt \& Manning (2000), but they accepted different concepts for the species and included diverse synonyms.

Jessop (1976) included 9 heterotypic synonyms in M. angustifolia, that resulted in creation of a very wide species concept including for instance definite Massonia species (such as Massonia longipes Baker (1897: 411)), together with several names corresponding to the current concept of Daubenya marginata (Willd. ex Kunth 1843: 299) Manning \& van der Merwe (2002a: 65), D. zeyheri (Kunth 1843: 298) Manning \& van der Merwe (2002b: 143) and D. namaquensis (Schlechter 1924: 150) Manning \& Goldblatt in Goldblatt \& Manning (2000: 713) (Manning \& van der Merwe 2002b). The inclusion of Daubenya species in the synonymy of M. angustifolia agrees with Jessop's (1976) morphological description of M. angustifolia, as having rather inconspicuous lower bracts, a trait different from Massonia which has large basal bracts enclosing the inflorescence. This solution would explain the infructescences in the original material of both $M$. angustifolia and M. lanceolata, as commented above, but not the flowering plants in those herbarium collections that bear much wider bracts.

Müller-Doblies \& Müller-Doblies (1997) followed in part Jessop's (1976) treatment but restricted the synonyms of M. angustifolia to only fit the current concept of Daubenya marginata (Manning \& van der Merwe 2002b).

Contrary to Jessop (1976) and Müller-Doblies \& Müller-Doblies (1997), Manning \& van der Merwe (2002a) concluded that the lectotype of Massonia angustifolia (UPS-THUNB7990, Fig. 10b, c) does not fit with Daubenya but with a Massonia species that they finally synonymised under Massonia echinata. These authors also excluded the three infructescences from the lectotype material. Moreover, Manning \& van der Merwe (2002a) regarded M. angustifolia as a "smooth-leaved form of $M$. echinata, which is common along the Roggeveld Escarpment and is extremely variable in leaf vestiture, even within populations". Similarly, Manning \& Goldblatt (2003, 2013) accepted Massonia echinata sensu Müller-Doblies \& Müller-Doblies (1997) and included M. angustifolia as synonym.

However, study of the type material of M. angustifolia reveals further information that refutes the concepts presented for that species since Aiton (1789).

As indicated above, the original material of both M. angustifolia and M. lanceolata include plants of a Massonia in flower, together with infructescences that probably corresponds to a Daubenya species. As Massonia angustifolia has priority over $M$. lanceolata, and the typification of the former name has not yet been correctly made, we select below the collection LINN 414.2 as the lectotype of M. angustifolia. Similarly to Manning \& van der Merwe (2002a), we exclude the infructescence present in the collection S10-14149 from the type material of M. angustifolia.

The flowering plants in the original material of both M. angustifolia and M. lanceolata (Fig. 10) show large, wide bracts enclosing the subcapitate inflorescence; flowers with a narrow perigone-filaments tube of 7-9 mm long; strongly reflexed free portions of perigone segments that bear a strong, inrolled, sigmoid curve at the base; filaments connate above the perigone to form a distinct column that surrounds the style for 1-2 $\mathrm{mm}$; free portions of filaments spreading, 7-8 $\mathrm{mm}$ long; and anthers with yellow pollen. The fact that the filaments are connate into a narrow tube above the perigone that surrounds the style could also explain why M. angustifolia was considered by various authors to be a member of Daubenya, as several species in this latter genus possess this character. However, other characters, such as the large bracts in M. angustifolia do not agree with that treatment.

The original materials of $M$. angustifolia and M. lanceolata were collected in the northern areas of the Roggeveld in November 1774. Masson, who accompanied Thunberg on that trip, sent material named Massonia angustifolia to Kew that formed the basis for the engraving of M. angustifolia in Hortus Kewensis (Aiton 1789) and later in Curtis's Botanical Magazine (Ker Gawler 1804). Therefore Masson's material must not be necessarily considered as conspecific with the original material provided by Thunberg, and therefore the basis of $M$. angustifolia. This is evident when comparing the flowers in the lectotypes of M. angustifolia and M. lanceolata (Fig. 10) with the illustrations by Aiton (1789) and Ker Gawler (1804) (Fig. 11a). In these two latter concepts, the flowers' free portion of the perigone segments are reflexed with only a slight sigmoid curve at the base, not distinctly inrolled as in the type; the filaments are not distinctly connate above the perigone segments, and the anthers in Ker Gawler's (1804) illustration are blue.

In summary, study of the type material of Massonia angustifolia and M. lanceolata show remarkable morphological differences with regards to the concept of the former species by most authors after its original description. Further studies are needed to elucidate the true identity of M. angustifolia, which is the focus of our current research.

As shown above, neither Massonia echinata nor M. angustifolia can be applied to the concepts of the plants usually known with those names from the Roggeveld and the Bokkeveld the escarpments. Therefore, two new species need to be described to accommodate the plants occurring in each of the escarpment sections mentioned above, named M. roggeveldensis and Massonia pseudoechinata, respectively. 
Massonia angustifolia Linnaeus fil. (1782: 193). Type (lectotype, here designated):- SOUTH AFRICA. without locality. Thunberg s.n. (LINN 414.2!, Fig. 10a)

—Massonia lanceolata Thunberg (1782: 40). Type (lectotype designated by Manning \& van der Merwe 2002a: 65):-SOUTH AFRICA. Crescit in summo monte Onderste Roggefelt, Thunberg s.n. (UPS-THUNB 7990!, only the two complete plants in flower in the middle of the voucher, excluding the three infructescences) (Fig. 10b,c).

\section{Description of new Massonia species}

Massonia roggeveldensis Mart.-Azorín, M.Pinter \& Wetschnig, sp. nov. = Massonia angustifolia sensu Ker Gawl. (1804) non L.f. (1782).

Species notabilis combinatione propia characterum ab ceteris speciebus Massoniae valde distincta. Folia omnino laevia. Flores albicantes, tubo longo strictissimo (ca. 12-22 × $2 \mathrm{~mm}$ ) longitudine ovarium valde occultante, et segmentis perigonii $(\mathrm{ca} .6-8 \times 1.5-2 \mathrm{~mm})$ reflexis (non revolutis), a basi sigmoideo-curvatis et ad apicem aliquando viridi-maculatis. Antherae statu clauso ca. $3 \times 1 \mathrm{~mm}$, cyanellae; polline cyanello concoloro. Ovarium obclavatum, ca. 4-6 $\times 1.8-2.1 \mathrm{~mm}$, in stylo gradualiter desinente. Semina ignota.

Type:-SOUTH AFRICA. Northern Cape. Sutherland (3220): Voëlfontein farm, Sutherland C.P. (-AD), 4800 feet elevation, 10 May 1969, L. I. Hall 225 (holotype PRE0048784! Sheet II; isotypes PRE0048784! Sheet I, NBG88386! Sheet I, NBG88386! Sheet II, NBG! [photos taken in habitat]).

Deciduous geophyte. Bulb ovoid to subglobose, 1.2-2.5 $\times 1-2 \mathrm{~cm}$, with white, fleshy bulb scales covered by dark brown to blackish, leathery outer tunics. Leaves 2, synanthous, opposite, appressed to the ground, ovoid to lanceolate, with an acute or obtuse apex and an apicule 1-3 mm long, limb 2-5 $\times 2-3.5 \mathrm{~cm}$, entire, with minutely papillosedenticulate margins; adaxial side dark green, smooth; abaxial side green, smooth; petiole ca. $1 \mathrm{~cm}$ long. Inflorescence a dense, subcapitate raceme, up to $2 \mathrm{~cm}$ long, with up to 40 flowers, shortly overtopping ground level. Bracts narrowly obovate to lanceolate, attenuate, $17-28 \times 3-10 \mathrm{~mm}$, green in the upper half with white membranous margins and base, glabrous, entire, sometimes distinctly purple in the lower parts. Pedicels at anthesis $7-14 \mathrm{~mm}$ long. Flowers long, narrowly tubular, not distinctly widening at the end of the tube. Perigone pure white; free segments $6-10 \times 1.5-2 \mathrm{~mm}$, sometimes with a short greenish central band at the tip, straight and erect in bud, strongly reflexed with a sigmoid curve at the base at anthesis but not distinctly inrolled; perigone-filaments tube 14-19 $\times$ ca. $2 \mathrm{~mm}$, narrowly cylindrical, not widening in the upper portion, with an almost closed mouth surrounding the style, the ovary deeply included within the tube. Filaments long-attenuate, spreading at anthesis, slightly arcuate, white, $8-12 \mathrm{~mm}$ long, connate at the base for ca. $0.5 \mathrm{~mm}$ above the perigone; anthers oblong, pale blue, ca. $3 \times 1 \mathrm{~mm}$ when closed, dorsifixed, with blue pollen. Ovary conical to suboblong, white with purplish flush, 4-6 $\times 1.8-2.1 \mathrm{~mm}$, gradually tapering to the style. Style white, thickened, gradually tapering to the apex, erect, $18-22 \mathrm{~mm}$ long at anthesis. Capsules and seeds unknown. Figs. 11b, 12.

Etymology:- Species named after its local distribution, restricted to the Roggeveld Escarpment in South Africa (roggeveldensis, $-e$ : from or native to the Roggeveld).

Phenology:-Massonia roggeveldensis flowers around May and June in the wild.

Habitat:-Massonia roggeveldensis is found at altitudes between 1300 and $1500 \mathrm{~m}$ in elevation, where it grows in vegetation classified as Roggeveld Karoo (SKt3) and Roggeveld Shale Renosterveld (FRs3). The Roggeveld is climatically one of the most peculiar regions of southern Africa, due to the unusual combination of high altitude, a landlocked continental position and at a transition between two major climatic systems responsible for winter- and summer-rainfall regimes. It is a semidesert region under the slight influence of a rainshadow with a mean annual precipitation reaching around $230 \mathrm{~mm}$. Pronounced precipitation peaks are in March and June with very scarce precipitation in December and January and a high frequency of low temperatures in autumn and winter with an average of 56 frost days per year, with Sutherland having the reputation as the coldest place in South Africa (Mucina \& Rutherford 2006).

Distribution:- This species is restricted to the Roggeveld Escarpment (Fig. 6). 


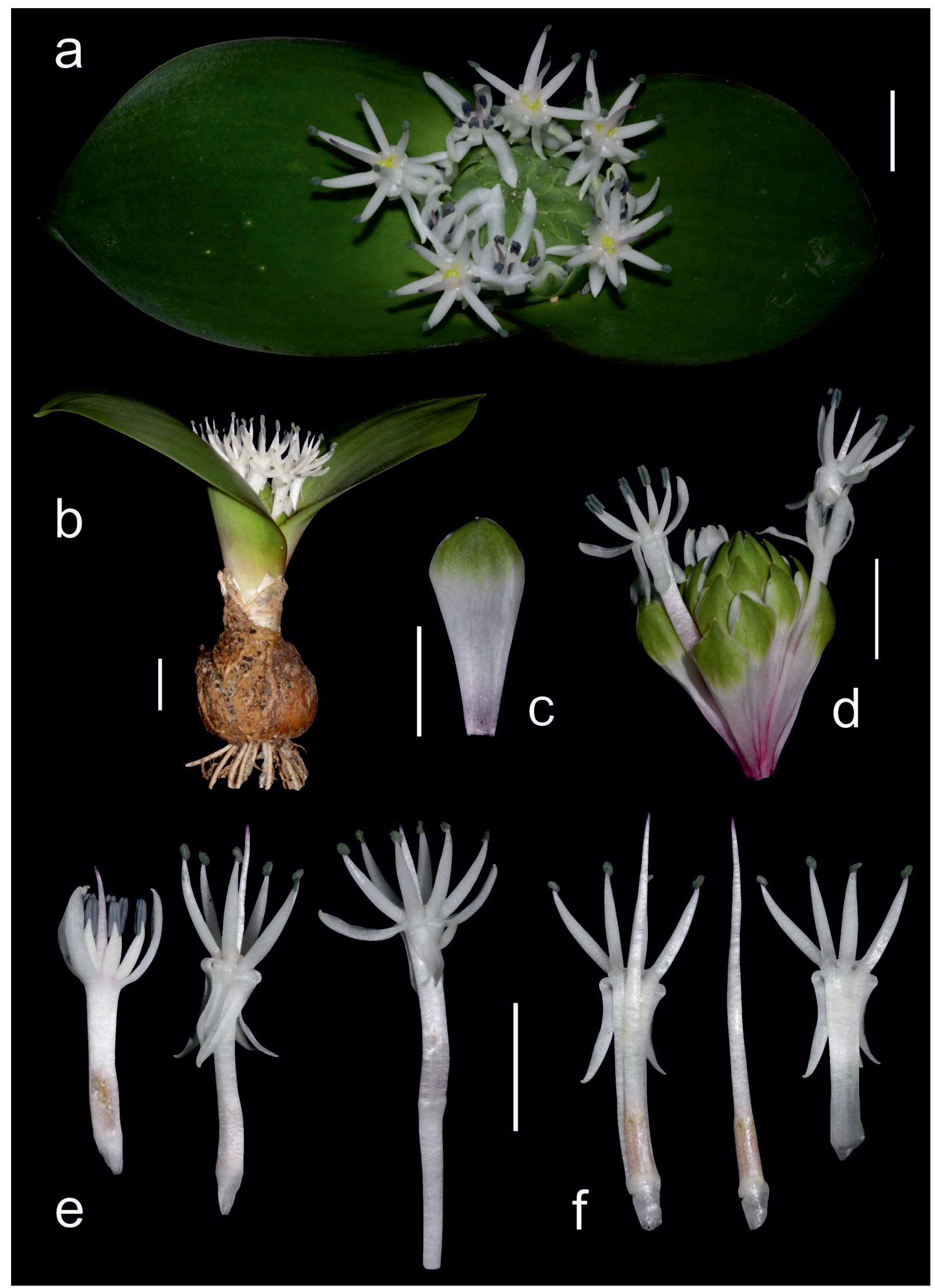

FIGURE 12. Massonia roggeveldensis Mart.-Azorín et al. in cultivation grown from seeds from near Middelpos, Roggeveld, Northern Cape Province, South Africa (corresponding to G.C. Summerfield 2506). a. Plant in apical view; b. Plant in lateral view; c. Bract, abaxial side; d. Inflorescence in lateral view; e. Flowers with closed and open anthers, lateral view; f. Dissected flower with open anthers and gynoecium. Scale bars $1 \mathrm{~cm}$. 
Taxonomic relationships:-Masson sent materials from the Roggeveld identified as Massonia angustifolia to Kew. This material serves as the basis for Aiton's (1789) and Ker Gawler's (1804) (Fig. 11a) characterizations and illustrations of $M$. angustifolia. However, as shown above, this species concept strongly differs from the morphology in the original material of both M. lanceolata and M. angustifolia (Fig. 10), that shows free portions of perigone segments strongly reflexed and inrolled at the base; filaments distinctly connate at the base above the perigone for ca. 1-2 mm; and yellow anthers and pollen. However, the plants from the Roggeveld, as characterised by Aiton (1789) and Ker Gawler (1804) (Fig. 11a), show the free portion of tepals reflexed, but not showing a strong or inrolled sigmoid curve at the base; spreading filaments that are shortly connate above the perigone for less than $1 \mathrm{~mm}$, and blue anthers and pollen. Therefore, we here described a new species to accommodate the plants from the Roggeveld, namely $M$. roggeveldensis, a species related to $M$. pseudoechinata but differing by morphological characters and biogeography.

Massonia roggeveldensis is related to $M$. pseudoechinata, M. dentata and M. calvata based on flower morphology (Table 1), but floral and vegetative characters support the recognition of all these species (Martínez-Azorín et al. 2014a). These species are allopatric, restricted to the Bokkeveld (M. pseudoechinata), Roggeveld (M. roggeveldensis), Nuweveldberge (M. dentata) and Sneeuberge (M. calvata) sections of the Great Escarpment, showing distinct biogeographic and climatic differences.

Additional materials studied (paratypes):-SOUTH AFRICA. Northern Cape. Sutherland (3220): Voëlfontein farm, Sutherland C.P. (-AD), 4800 feet elevation, 20 May 1969, L. I. Hall 225 (Photos by W.F. Barker NBG153631!); Sutherland (3220): $5 \mathrm{~km}$ N of Komsberg Pass summit (-DB), flats, 28 May 1998, J.C. Manning 2166 (NBG!); Williston (3120): $66 \mathrm{~km}$ from Calvinia on Blomfontein road to Middelpos, (-CC), shallow soil over flat rock slabs, seasonally wet, 4 June 1980, P. Goldblatt 5534 (MO2773817!); Williston (3120): Roggeveld, near Middelpos (-CC), ex hort. 16 October 2013, G.C. Summerfield 2506 (as Daubenya marginata) (GZU!); Roggeveld, grown from seeds collected and distributed by Silverhill Seeds as Daubenya marginata, Nhu Nguyen photo! http://www.pacificbulbsociety.org/ pbswiki/index.php/Massonia; Sutherland, 29 July 1969, F. Stayner s.n. (Photos by W.F. Barker, NBG!).

\section{Massonia pseudoechinata Mart.-Azorín, M.Pinter \& Wetschnig, sp. nov.}

Species notabilis combinatione propia characterum ab ceteris speciebus Massoniae bene distincta. Folia pustulata symmetricis pustulis minutis (ca. 0.2-0.4 mm diametro) plus minusve numerosis (1-60) obsita, quae ad apicem papilla minuta (0.2-0.5 mm) declinata et valida munitas. Flores albicantes, tubo longo (ad $15 \mathrm{~mm})$ et strictissimo longitudine ovarium valde occultante, et segmentis perigonii 6-7 $\times 1.5-2 \mathrm{~mm}$, reflexis et valde revolutis, a basi sigmoideo-curvatis et ad apicem viridi-maculatis. Antherae statu clauso ca. 2-3 $\times 1-1.5 \mathrm{~mm}$, cyanellae; polline cyanello concoloro. Ovarium conicum vel suboblongum, ca. 5-6×1.8-2.1 mm, in stylo gradualiter desinente. Semina 1.5-2.1 × 1.3-2 mm, globosa, nigra, laevia.

Type:-SOUTH AFRICA. Northern Cape. Calvinia (3119): Edge of street in Nieuwoudtville (-AC), 10 June 1955 [in flower], D.M. Comins 1142 (holotype PRE0050957-0!; isotypes L1452891!, GRA!).

Deciduous geophyte. Bulb ovoid to subglobose, $1.5-3.5 \times 1.2-3 \mathrm{~cm}$, with white, fleshy bulb scales covered by pale brown, papery outer tunics. Leaves 2, synanthous, opposite, appressed to the ground, ovoid to obovoid, with an obtuse apex and a short apicule about 1-2 mm long, limb 3-12 $\times 2.5-8 \mathrm{~cm}$, with narrow, membranous, denticulate to shortly ciliate-fimbriate margins; adaxial side pale green, with 1-60 symmetrical, cone-like, emergences per $\mathrm{cm}^{2}$, which are $0.2-0.4 \mathrm{~mm}$ in diameter, with a deflexed, thickened, smooth trichome on top, $0.2-0.5 \mathrm{~mm}$ long; abaxial side smooth, green; petiole $0.5-2 \mathrm{~cm}$ long. Inflorescence dense, subcapitate raceme, up to 2-4 $\mathrm{cm}$ long, many-flowered (with up to 90 flowers), shortly overtopping ground level. Bracts narrowly obovate, attenuate at the apex, 20-31 ×6-12 mm, green in the upper half with white membranous margins and base, glabrous, entire, sometimes distinctly purple in the lower half at fruiting time. Pedicels at anthesis $14-20 \mathrm{~mm}$ long. Flowers long, narrowly tubular, not distinctly widening at the end of the tube. Perigone pure white; free segments 6-10 $\times 1.5-2 \mathrm{~mm}$, entire, with a short greenish central band at the tip, straight and erect in bud, strongly reflexed and inrolled with a distinct sigmoid curve at the base at anthesis; perigone-filaments tube 10-15 $\times 2-3 \mathrm{~mm}$, narrowly cylindrical, not widening in the upper portion, with a hexagonal mouth showing strongly convex sides, giving the appearance of having 6 gibbosities, the ovary deeply included in the tube. Filaments long-attenuate, spreading at anthesis, slightly arcuate, white, $8-12 \mathrm{~mm}$ long, connate at the base for ca. $1 \mathrm{~mm}$ above the perianth segments; anthers oblong, pale blue, $2-3 \times 1-1.5 \mathrm{~mm}$ when closed, dorsifixed, with blue pollen. Ovary conical to suboblong, green to pale yellow, 4-6 $\times 1.8-2.1 \mathrm{~mm}$, gradually tapering to the style. Style white, gradually tapering into the apex, erect, $15-17 \mathrm{~mm}$ long at anthesis. Capsule ovate in lateral view, trigonous with blunt edges in apical view, 10-17 × 4-9 mm. Seeds globose, black, $1.5-2.1 \times 1.3-2 \mathrm{~mm}$, smooth. Figs. 3d, 4d, 5d, 13. 


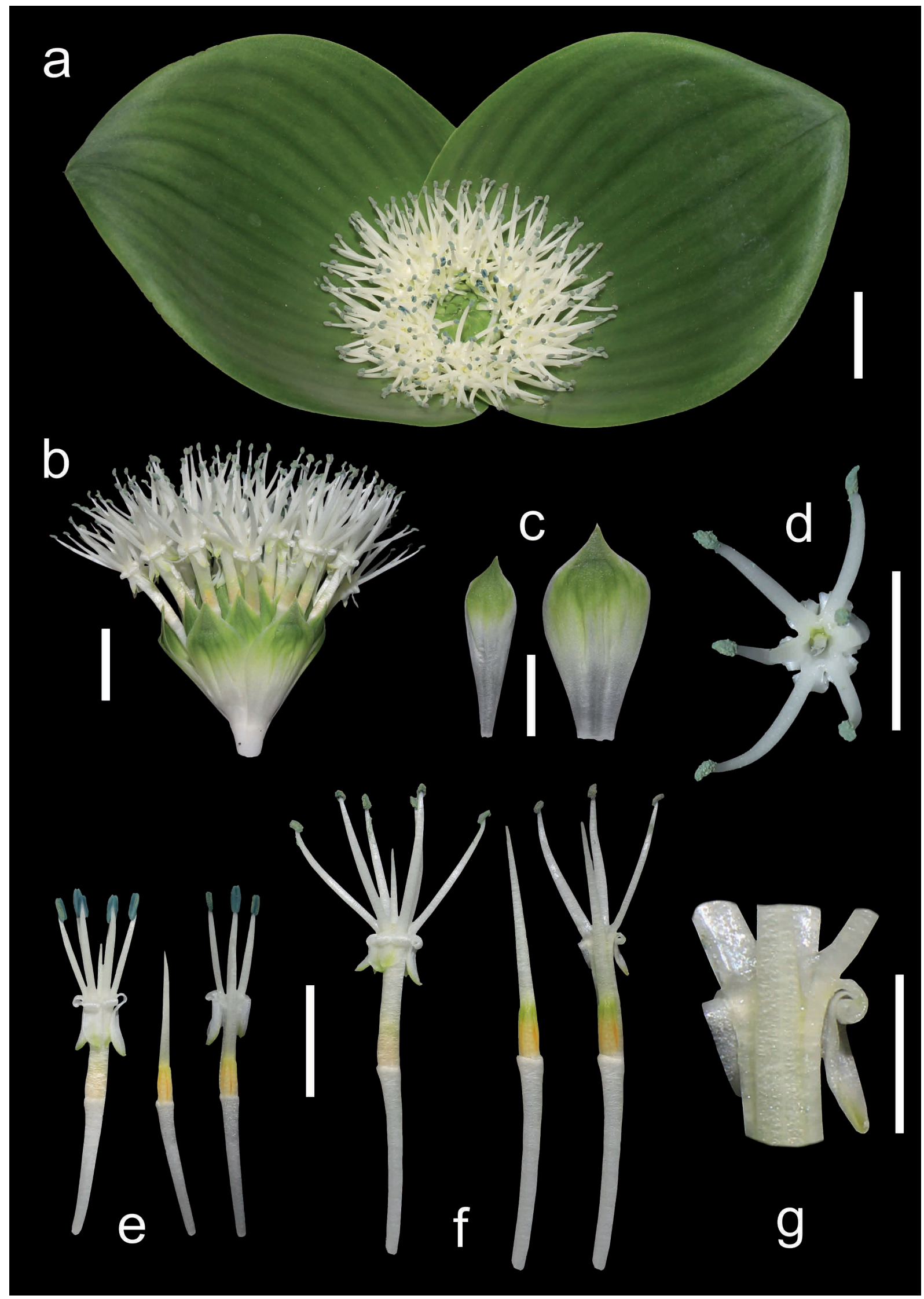

FIGURE 13. Massonia pseudoechinata Mart.-Azorín et al. in cultivation from Vanrhyns Pass, W of Nieuwoudtville, Northern Cape province, South Africa (corresponding to WW03970). a. Plant in apical view; b. Inflorescence in lateral view; c. Bracts, showing abaxial sides; d. Flowers with open anthers, apical view; e. Flower and dissected flower with close anthers, lateral view; f. Flower and dissected flower with open anthers, lateral view; g. Detail of the sigmoid and inrolled free portion of perigone segments. Scale bars a-f: $1 \mathrm{~cm}$; $\mathrm{g}$ : $\mathrm{mm}$. 
Etymology:-The specific epithet (pseudoechinatus, $-a,-$ um: false echinata, resembling echinata) refers to the general confusion and misapplication of the name Massonia echinata to this species within the last decades by most authorities.

Phenology:-Massonia pseudoechinata flowers in May and June in the wild.

Habitat:-Massonia pseudoechinata is found in loamy soils at altitudes spanning 700 and $800 \mathrm{~m}$; the surrounding vegetation is classified as either Bokkeveld Sandstone Fynbos (FFs1) or Vanrhynsdorp Shale Renosterveld (FRs1) or Nieuwoudtville Shale Renosterveld (FRs2); the region is characterised by winter rainfall peaking from May to August, with a mean annual precipitation of $290 \mathrm{~mm}$ and 3-10 days of frost per year (Mucina \& Rutherford 2006).

Distribution:- This species is known to us only from the surroundings of Nieuwoudtville and Vanrhyns Pass (Fig. 6).

Taxonomic relationships:-Massonia pseudoechinata was apparently first illustrated in part by Müller-Doblies \& Müller-Doblies (1997) under Massonia echinata. From that point on, several works accepted this species concept for M. echinata (Manning \& van der Merwe 2002a, Manning \& Goldblatt 2003, 2013), including among other synonyms also M. angustifolia. However, as shown above, neither M. echinata nor M. angustifolia, the latter including M. lanceolata, can be applied to Müller-Doblies \& Müller-Doblies's (1997) concept of Massonia echinata.

In the framework of a taxonomic revision of Massonia, we were not able to assign any of the described species of Massonia to Müller-Doblies \& Müller-Doblies's concept of M. echinata, excluding the populations from the Karoo National Park that were recently described as Massonia dentata. Therefore, we here describe a new species, namely M. pseudoechinata, to accommodate these plants.

Massonia pseudoechinata can be easily distinguished by the leaves with scarce to numerous small emergences with a declinate, smooth trichome on top (Fig. 5d); flowers white with long and narrow perigone tube, deeply enclosing the ovary; the strongly reflexed and inrolled perigone segments bearing a distinct sigmoid curve at the base; the blue anthers and pollen; and the obclavate gynoecium, gradually tapering from the ovary to the tip of the style (Fig. 13). The general flower morphology and especially the obclavate ovary link M. pseudoechinata to M. mimetica (MartínezAzorín et al. 2013) and M. bakeriana (Pinter et al. 2015), but it differs by clear vegetative and floral characters.

Additional specimens studied (paratypes):-SOUTHAFRICA. Northern Cape. Calvinia (3119): Nieuwoudtville, Clanwilliam Division, Fld. at Kirstenbosch, 1 June 1927, R.H. Compton 153026 (BOL111913!); Calvinia (3119): Calvinia Div., near Nieuwoudtville (-AC), May 1946, C.L. Leipoldt 4208 (BOL61534!); Calvinia (3119): ca. $1 \mathrm{~km}$ W of Nieuwoudtville (-AC), shallow soil over flat sandstone rock, 3 June 1980, P. Goldblatt 5509 (MO2773793!, S15-24617!); Calvinia (3119): Glenlyon farm, S of Nieuwoudtville trekpath, near entrance to farm (-AC), 3 June 1980, P. Goldblatt 5524 (MO2773825!); Calvinia (3119): Calvinia Div. near Niewoudtville (-AC), 25 May 1946, fld. BH 12 June 1946, C.L. Leipoldt 4210 (BOL61475!); Calvinia (3119): near Niewoudtville (-AC), May 1950, C.L. Leipoldt 4210 (BOL112139!); Calvinia (3119): Bokkeveld, ex hort. May 1918, R. Marloth 8033 (PRE0049600-0!, PRE0049601-0!); Calvinia (3119): Calvinia C.P., near Grasberg, Nieuwoudtville (-AC), 8 August 1961, W.F. Barker 9370 (NBG71360!); Calvinia (3119): Calvinia C.P., near Grasberg, Nieuwoudtville (-AC), 6 June 1962, W.F. Barker 9370 (NBG71359!); Calvinia (3119): top of Vanrhyns Pass (-AC), 23 May 1947, G.G. Smith 6450 sub NBG148/46 (NBG71362!); Calvinia (3119): top of Vanrhyns Pass (-AC), 27 May 1998, J.C. Manning 2156 (NBG!); Calvinia (3119): Calvinia Div., summit of Vanrhynpass (-AC), 31 May 1970, H. Hall 3580 (NBG94135!); Calvinia (3119): Calvinia Div., summit of Vanrhynpass (-AC), 15 May 1971, H. Hall 3580 (NBG94135!); Calvinia (3119): Top of Vanrhyn's Pass (-AC), ex hort. May 1969, D.S. Hardy 2501 (PRE0048785-0!); Calvinia (3119): ca. 9 km W of Nieuwoudtville, Vanrhyn's Pass Lookout (-AC), 806 m elevation, 22 September 2009, WW03970 (GZU photo!); ibidem, WW03971 (GZU photo!); ibidem, WW03972 (GZU photo!); Calvinia (3119): Hantam Botanical Garden (-AC), ca. 737 m elevation, 23 September 2009, WW03974 (GZU photo!); ibidem, WW03975 (GZU photo!); Calvinia (3119): South of Nieuwoudtville (-AC), 701 m elevation, 16 June 2009, A. Horstmann (iSpot photo!, http://www.ispotnature. org/node/511394?nav=parent_ob as M. echinata).

\section{A new combination in Massonia}

Dinter (1931) described Haemanthus sessiliflorus Dinter (1931: 258) from southern Namibia. Merxmüller \& Roessler (1973) presented further data and illustrations of flowers of that species, concluding that it belongs to Massonia, and they mentioned that Jessop would treat this species under Massonia echinata in his revision of the genus. Ultimately Jessop (1976) did not mention this species in his study. 
Müller-Doblies \& Müller-Doblies (1997) combined H. sessiliflorus in Massonia, however, they did not include the reference of the basionym in full, and therefore the combination was not validly published according to article 41A.1 (ICN, McNeill et al. 2012). The cited combination in Massonia is presented below.

Massonia sessiliflora (Dinter) Mart.-Azorín, M.B.Crespo, M.Pinter \& Wetschnig comb. nov. Basionym:-Haemanthus sessiliflorus Dinter (1931: 168).

\section{Acknowledgements}

This work was partly supported by Fundación Ramón Areces (Spain), H2020 Research and Innovation Staff Exchange Programme of the European Commission, project 645636: 'Insect-plant relationships: insights into biodiversity and new applications' (FlyHigh), University of Alicante (Spain), Karl-Franzens-University Graz (Austria), Rhodes University (Dept. of Botany) and the Selmar Schonland Herbarium (GRA). We thank D. Bellstedt, L. Mucina, C. Huber and A. Martínez Soler for valuable help with the fieldwork. The Department of Environment and Nature Conservation of Northern Cape Province and CapeNature of Western Cape Province provided permission to collect herbarium specimens (collecting permits numbers FLORA046/2010, FLORA047/2010, FLORA069/2011, FLORA070/2011, FLORA061/2/2015 FLORA062/2/2015, AAA008-00031-0028 and 0028-AAA008-00203 respectively). J.C. Manning is thanked for allowing us to study the Massonia materials on loan at NBG. We also thank K. Achner, A. Brudermann, S. Laure, E. Stabentheiner and V. Zengerer for poducing the seed and SEM images. We acknowledge the help of all herbaria curators who kindly provided material and information. We thank M. Hjertson from the Museum of Evolution, Botany Section, Uppsala University for providing scans from UPS-THUNB. J. Gregson and A. Hart from the British Museum kindly sent valuable information and images of Masson's paintings at BM. L. Brooks and the Linnean Society of London are thanked for sending images of types at LINN and for permission to be reproduced here. We also would like to thank all the numerous garden and plant enthusiasts who publish valuable information and images on plants on the internet and who contribute substantially to the increase of knowledge.

\section{References}

Aiton, W. (1789) Hortus kewensis 1. George Nicol, London, 496 pp.

Aiton, W. (1811) Hortus kewensis, 2nd edition 2. Longman, Hurst, Rees, Orme \& Brown, London, 432 pp.

Baker, J.G. (1870) A revision of the genera and species of herbaceous capsular gamophyllous Liliaceae. Journal of the Linnean Society. Botany 11: 349-436.

Baker, J.G. (1886) New Cape Liliaceae. Journal of Botany 24: 335-336.

Baker, J.G. (1897) Liliaceae. In: Thiselton-Dyer, W.T. (Ed.) Flora Capensis 6. Reeve and Co., London, pp. $253-525$.

Bradlow, F.R. (1994) Francis Masson's account of three journeys at the Cape of Good Hope 1772-1775. Tablecloth Press, Cape Town, $183 \mathrm{pp}$.

Dinter, M.K. (1931) XXXIX. K. Dinter, Diagnosen neuer südwestafrikanischer Pflanzen. Repertorium Specierum Novarum Regni Vegetabilis 29: 253-272.

Forbes, V.S. (1965) Pioneer travellers of South Africa. Balkema, Cape Town, Amsterdam, 177 pp.

Forbes, V.S. (Ed.) (1986) Carl Peter Thunberg - Travels at the Cape of Good Hope, 1772, 1775. Van Riebeeck Society, Cape Town, 366 pp.

Glen, H.F. \& Germishuizen, G. (2010) Botanical exploration of southern Africa, edition 2. Strelitzia 26. South African National Biodiversity Institute, Pretoria, $489 \mathrm{pp}$

Goldblatt, P. \& Manning, J.C. (2000) Cape Plants. A Conspectus of the Cape flora of South Africa. Strelitzia 9. National Botanical Institute, Pretoria \& Missouri Botanical Garden, Missouri, 743 pp.

Gunn, M. \& Codd, L.E. (1981) Botanical exploration of Southern Africa. Botanical Research Institute, A.A.Bakelma, Cape Town, 400 pp.

Houttuyn, M. (1780) Natuurlijke Historie of uitvoerige Beschryving der Dieren, Planten en Mineraalen, volgens het Samenstel van der Heer Linnaeus II, 12, Amsterdam, 558 pp.

IPNI (2015) The International Plant Names Index. Available from: http://www.ipni.org (accessed February 2015)

Jessop, J.P. (1976) Studies in the bulbous Liliaceae in South Africa 6. The taxonomy of Massonia and allied genera. Journal of South African Botany 42: 401-437. 
Karsten, M. (1959) Francis Masson, a gardener-botanist who collected at the Cape. III. Masson's Journeys at the Cape (continued). Journal of South African Botany 25: 283-310.

Ker Gawler, J.B. (1804) Massonia angustifolia. Curtis's Botanical Magazine 19: t. 736.

Kunth, C.S. (1843) Enumeratio plantarum omnium hucusque cognitarum, secundum familias naturales disposita, adjectis characteribus, differentiis et synonymis 4. Cottae, J.G., Stuttgarttiae et Tubingae, 752 pp.

Leistner, O.A. \& Morris, J.W. (1976) Southern African Place Names. Annals of the Cape Provincial Museum 12: 1-565.

Linnaeus fil., C. (1782) Supplementum plantarum systematis vegetabilium. Orphantrophius, Braunschweig, 467 pp.

Manning, J.C. \& Goldblatt, P. (2003) Hyacinthaceae. In: Germishuizen, G. \& Meyer, N.L. (Eds.) Plants of Southern Africa: An annotated checklist [4th approach to the List of Species of Southern African Plants]. Strelitzia 14: 1054-1071.

Manning, J.C. \& Goldblatt, P. (2012) Plants of the Greater Cape Floristic Region 1: the Core Cape flora. Strelitzia 29. South African National Biodiversity Institute, Pretoria, $853 \mathrm{pp}$.

Manning, J.C. \& Goldblatt, P. (2013) Hyacinthaceae. In: Snijman, D.A. (Ed.) Plants of the Greater Cape Floristic Region 2: the Extra Cape flora. Strelitzia 30: 69-92.

Manning, J.C. \& Van der Merwe, A.M. (2002a) Notes on African Plants. Hyacinthaceae. A new combination in Daubenya. Bothalia 32: $63-83$.

Manning, J.C. \& Van der Merwe, A.M. (2002b) Systematics of the genus Daubenya (Hyacinthaceae: Massonieae). Bothalia 32: $133-150$. http://dx.doi.org/10.4102/abc.v32i2.478

Manning, J.C., Goldblatt, P. \& Fay, M.F. (2004) A revised generic synopsis of Hyacinthaceae in Sub-Saharan Africa, based on molecular evidence, including new combinations and the new tribe Pseudoprospereae. Edinburgh Journal of Botany 60: 533-568.

Martínez-Azorín, M., Crespo, M.B. \& Juan, A. (2007) Taxonomic revision of Ornithogalum subg. Cathissa (Salisb.) Baker (Hyacinthaceae). Anales del Jardín Botánico de Madrid 64: 7-25. http://dx.doi.org/10.3989/ajbm.2007.v64.i1.47

Martínez-Azorín M., Crespo, M.B. \& Juan, A. (2009) Taxonomic revision of Ornithogalum subg. Beryllis (Hyacinthaceae) in the Iberian Peninsula and the Balearic Islands. Belgian Journal of Botany 142: 140-162.

Martínez-Azorín, M., Pinter, M., Crespo, M.B., Pfosser, M. \& Wetschnig, W. (2013) Massonia mimetica (Hyacinthaceae, Hyacinthoideae), a new remarkable species from South Africa. Stapfia 99: 187-197.

Martínez-Azorín, M., Clark, V.R., Pinter, M., Dold, A.P., Crespo, M.B., Barker, N.P., Pfosser, M. \& Wetschnig, W. (2014a) Massonia dentata (Asparagaceae, Scilloideae), a new species from the Nuweveldberge, southern Great Escarpment, South Africa and typification of M. calvata. Phytotaxa 175 (4): 201-215.

http://dx.doi.org/10.11646/phytotaxa.175.4.2

Martínez-Azorín, M., Pinter, M., Deutsch, G., Brudermann, A., Dold, A.P., Crespo, M.B., Pfosser, M. \& Wetschnig, W. (2014b) Massonia amoena (Asparagaceae, Scilloideae), a striking new species from the Eastern Cape, South Africa. Phytotaxa 181 (3): $121-137$. http://dx.doi.org/10.11646/phytotaxa.181.3.1

Martínez-Azorín, M., Dold, A.P., Pinter, M., Slade, J., Crespo, M.B., Milkuhn, G. \& Wetschnig, W. (2015) Massonia obermeyerae (Asparagaceae, Scilloideae), a new species from South Africa. Phytotaxa 205 (1): 39-50.

http://dx.doi.org/10.11646/phytotaxa.205.1.3

Masson, F. (1776) An account of three journeys from the Cape Town into the southern parts of Africa; undertaken for the Discovery of new Plants, towards the Improvement of the Royal Botanical Gardens at Kew. Philosophical Transactions of the Royal Society of London 66: 268-317. http://dx.doi.org/10.1098/rstl.1776.0017

McNeill, J., Barrie, F.R., Buck, W.R., Demoulin, V., Greuter, W., Hawksworth, D.L. Herendeen, P.S., Knapp, S., Marhold, K., Prado, J., Prud'homme van Reine, W.F., Smith, G.F., Wiersema, J.H. \& Turland, N.J. (Eds.) (2012) International Code of Nomenclature for algae, fungi, and plants (Melbourne Code). Adopted by the Eighteenth International Botanical Congress Melbourne, Australia, July 2011. [Regnum Vegetabile 154]. A.R.G. Gantner, Ruggell, 240 pp.

Merxmueller, H. \& Roessler, H. (1973) Eine bisher verkannte Liliacee der Gattung Massonia in Südwestafrika. Mitteilungen der Botanischen Staatssammlung München 11: 83-85.

Mucina, L. \& Rutherford, M.C. (Eds.) (2006) The Vegetation of South Africa, Lesotho and Swaziland, Strelitzia 19. South African National Biodiversity Institute, Pretoria, $807 \mathrm{pp}$.

Müller-Doblies, U. \& Müller-Doblies, D. (1997) A partial revision of the tribe Massonieae (Hyacinthaceae). Feddes Repertorium 108: 49-96.

http://dx.doi.org/10.1002/fedr.19971080106

Müller-Doblies, U. \& Müller-Doblies, D. (2010) De Liliifloris Notulae 8. Two new Massonia species (Hyacinthaceae) from South Africa. Feddes Repertorium 121: 127-132. http://dx.doi.org/10.1002/fedr.201000022 
Panzer, G.W.F. (1784) Massonia depressa. Des Ritters Carl von Linné Königlich Schwedischen Leibarztes c. c. vollständiges Pflanzensystem nach der dreyzehnten lateinischen Ausgabe und nach Anleitung des holländischen Houttuynischen Werks übersetzt und mit einer ausführlichen Erklärung ausgefertigt 11. Raspe, G.N., Nürnberg, 680 pp.

Pfosser, M., Wetschnig, W., Ungar, S. \& Prenner, G. (2003) Phylogenetic relationships among genera of Massonieae (Hyacinthaceae) inferred from plastid DNA and seed morphology. Journal of Plant Research 116: 115-132.

Pinter, M., Brudermann, A., Crespo, M.B., Deutsch, G., Martínez-Azorín, M., Müller-Doblies, U., Müller-Doblies, D., Pfosser, M. \& Wetschnig, W. (2013) Massonia citrina (Hyacinthaceae, Hyacinthoideae) - a new species from the Western Cape Province (South Africa). Phytotaxa 112 (2): 50-56.

http://dx.doi.org/10.11646/phytotaxa.112.2.3

Pinter, M., Martínez-Azorín, M., Crespo, M.B. \& Wetschnig, W. (2015) Massonia bakeriana (Asparagaceae, Scilloideae), a new pustulate species from the Northern Cape Province (South Africa). Phytotaxa 222 (1): 51-60. http://dx.doi.org/10.11646/phytotaxa.222.1.5

Poellnitz, K. (1946) Zwei neue Massonia-Arten aus Kapland. Portugaliae Acta Biologica. Série B 1: 384-385.

Raper, P.E. (1987) Dictionary of South African place names. Lowry Publishers, Johannesburg, 368 pp.

Schlechter, R. (1924) Drei neue Gattungen der Liliaceen aus Südafrika. Notizblatt des Botanischen Gartens und Museums zu BerlinDahlem. Berlin-Dahlem 9: 145-151.

Species-2000 (2015) Annual Checklist. Available from: http://www.sp2000.org/ (accessed February 2015)

Speta, F. (1998a) Hyacinthaceae. In: Kubitzki, K. (Ed.) The families and genera of vascular plants 3. Springer, Berlin, pp. 261-285. http://dx.doi.org/10.1007/978-3-662-03533-7_35

Speta, F. (1998b) Systematische Analyse der Gattung Scilla L. s.l. (Hyacinthaceae). Phyton (Horn) 38: 1-141.

Summerfield, A. (2004) A synopsis of the biosystematic study of the seven minor genera of the Hyacinthaceae. Bulbs Bulletin of the International Bulb Society 6: 24-36.

Thiers, B. (2015) Index Herbariorum: A global directory of public herbaria and associated staff. New York Botanical Garden's Virtual Herbarium. Available from: http://sweetgum.nybg.org/ih/ (accessed February 2015)

Thunberg, C.P. (1782) Nova genera Plantarum, quorum partem secundam. Johan Edman, Upsaliae, 11 pp.

Thunberg, C.P. (1783) Nova genera plantarum 2 in Acta medicorum suecicarum 1: 241-243.

Thunberg, C.P. (1794) Prodromus Plantarum Capensium: quas in promontorio Bonce Spei Africes. Johan Edman, Uppsala, 83 pp.

Thunberg, C.P. (1818) Flora Capensis, sistens plantas promontorii Bonae Spei Africes: secundum systema sexuale emendatum 2. Gerhard Bonier, Hafniae, 352 pp. http://dx.doi.org/10.5962/bhl.title.6685

Van der Merwe, A. (2002) A biosystematic study of the seven minor genera of the Hyacinthaceae. Ph.D. Thesis, University of Stellenbosch [unpublished].

Van der Merwe, A.M. \& Marais, E.M. (2002) Daubenya alba (Hyacinthaceae, tribe Massonieae), a new species from the Roggeveld, Northern Cape Province. South African Journal of Botany 68: 308-311.

Wetschnig, W., Pfosser, M. \& Prenner, G. (2002) Zur Samenmorphologie der Massonieae Baker 1871 (Hyacinthaceae) im Lichte phylogenetisch interpretierter molekularer Befunde. Stapfia 80: 349-379.

Wetschnig, W., Brudermann, A., Knirsch, W., Pinter, M. \& Pfosser, M. (2012) Massonia pustulata Jacq. 1791 and M. longipes Baker 1897 (Hyacinthaceae), two frequently misunderstood species - or how M. pustulata became depressed. Stapfia 97: 210-221.

Wetschnig, W., Martínez-Azorín, M., Pinter, M., Brudermann, A., Deutsch, G., Crespo, M.B., Dold, A.P. \& Pfosser, M. (2014) Massonia saniensis (Asparagaceae, Scilloideae), a new species from Lesotho. Phytotaxa 173 (3): 181-195.

http://dx.doi.org/10.11646/phytotaxa.173.3.1 